\title{
Prograde amphibolite facies to ultrahigh-pressure transition along Nordfjord, western Norway: Implications for exhumation tectonics
}

\author{
David J. Young, ${ }^{1}$ Bradley R. Hacker, ${ }^{1}$ Torgeir B. Andersen, ${ }^{2}$ \\ and Fernando Corfu ${ }^{2}$
}

Received 23 December 2004; revised 25 August 2006; accepted 22 September 2006; published 3 February 2007.

[1] The Nordfjord area of western Norway hosts one of the best known provinces of ultrahigh-pressure (UHP) rocks in the world, yet the nature of the transition from the UHP rocks into surrounding amphibolite-facies crust has remained unclear. New thermobarometry of phengite- and kyanite-bearing eclogites shows that this transition is unbroken by major structures: the pressure and temperature gradient increases smoothly over a horizontal distance of $\sim 20 \mathrm{~km}$, from high-pressure amphibolite facies $\left(\sim 1.5 \mathrm{GPa} / 600-700^{\circ} \mathrm{C}\right)$ through quartz eclogite $\left(\sim 2.4 \mathrm{GPa} / 600^{\circ} \mathrm{C}\right)$ into UHP eclogite $(>2.7 \mathrm{GPa} /$ $700^{\circ} \mathrm{C}$ ). These data support a model in which the Norwegian UHP province remained attached to lower pressure crust during exhumation. This requires that a large area of the Western Gneiss Region was metamorphosed and exhumed $\sim 60 \mathrm{~km}$ through the mantle, as a relatively coherent body. Citation: Young, D. J., B. R. Hacker, T. B. Andersen, and F. Corfu (2007), Prograde amphibolite facies to ultrahigh-pressure transition along Nordfjord, western Norway: Implications for exhumation tectonics, Tectonics, 26, TC1007, doi:10.1029/2004TC001781.

\section{Introduction}

[2] The profound subduction and exhumation of large UHP segments of continental crust deserves study because of the impact such processes must have had on the geodynamic and chemical evolution of the Earth. The signature metamorphism of such rocks has been documented in the exposed keels of many Phanerozoic orogenic belts around the world, but the mechanisms by which these rocks were exhumed from the mantle are still debated. This problem is not trivial because of the great size of some UHP-HP terranes $\left(>50,000 \mathrm{~km}^{2}\right.$ in China and Norway), the large vertical displacements required, and the stringent conditions necessary for the preservation of indicator minerals [Hacker and Peacock, 1995; Grasemann et al., 1998].

\footnotetext{
${ }^{1}$ Department of Geological Sciences, University of California, Santa Barbara, California, USA.

${ }^{2}$ Physics of Geological Processes and Department of Geosciences, University of Oslo, Oslo, Norway.

Copyright 2007 by the American Geophysical Union. 0278-7407/07/2004TC001781\$12.00
}

[3] Most exhumation models call upon normal faulting to unroof continental UHP rocks, and, indeed, normal faults/ shear zones do drape the highly metamorphosed internal zones of many UHP orogens. However, the fabrics and structures found in most such extensional zones are late, having developed at crustal pressures $(\leq 1.5 \mathrm{GPa})$, and little record of travel through mantle depths is typically preserved. If UHP terranes were subducted to depths as great as $150 \mathrm{~km}$, how did they rise out of the mantle?

[4] UHP continental crust must either remain attached to the mantle lithosphere during exhumation, or delaminate from it. Models of such processes include (1) displacement in the footwall of a postcollisional, lithospheric-scale normal fault system [Fossen, 2000]; (2) delamination from the downgoing slab and extrusion up the subduction channel as a buoyant, semicoherent pip [Chemenda et al., 1995] (Figure 1b); (3) delamination from the downgoing slab and diapiric ascent through the mantle wedge [Yin et al., 2001] (Figure 1c); or (4) buoyancy-driven flexural rebound of unloaded continental lithosphere [Andersen et al., 1991] (Figure 1d). A mixture of these modes may obtain in the Earth as boundary conditions and body forces evolve.

[5] Predictions from these models can be tested by examining the metamorphic transition from the HP and UHP units to surrounding lower pressure rocks. If the UHP terrane remained attached to less deeply subducted crust, a continuous structural and metamorphic transition to lower pressure rocks should be expected, whereas if delamination occurred, the contacts must be tectonic at some scale, with considerable excision of section likely. In the Dora Maira [Chopin et al., 1991] and Kokchetav [Yamamoto et al., 2000] UHP terranes, peak pressures drop dramatically ( $\sim 2 \mathrm{GPa}$ ) across major shear zones beneath the UHP rocks, favoring delamination. In the Dabie Shan, a similar basal thrust décollement has been proposed based on structural geometries of the HP rocks [Hacker et al., 2000] and the adjacent foreland section [Schmid et al., 1999], but the transition downward from higher pressure to lower pressure rocks is not exposed.

[6] This contribution presents new eclogite thermobarometry and $\mathrm{U} / \mathrm{Pb}$ geochronology to show that the transition to UHP rocks in the Nordfjord area of the Western Gneiss Complex of Norway is defined by a continuous temperature and pressure increase from high-P amphibolite to UHP eclogite. No identifiable peak pressure structure disrupts this transition, consistent with an interpretation that the 

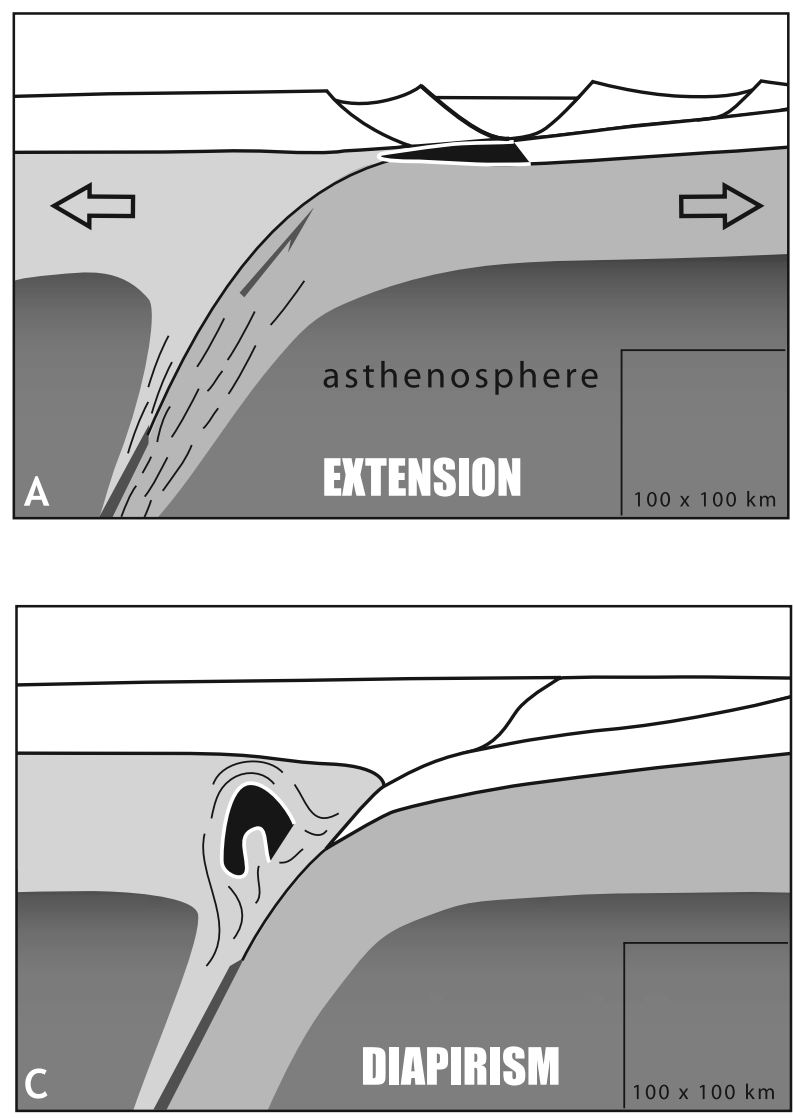
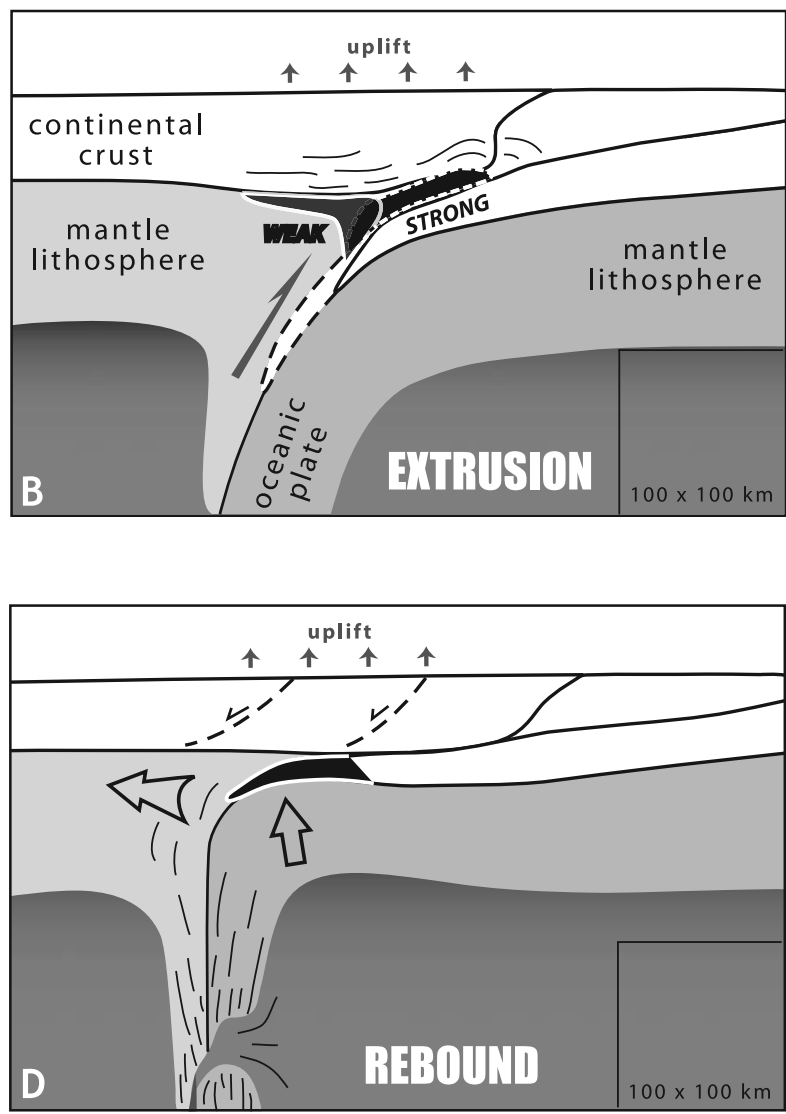

Figure 1. Summary of UHP exhumation models. (a) Displacement in the footwall of a lithosphericscale normal fault system; (b) delamination from the downgoing mantle and extrusion up the subduction channel as a buoyant pip; (c) delamination from the downgoing slab and diapiric ascent through the mantle wedge; and (d) failure of the slab at greater depth and flexural rebound to propel a broadly coherent crustal section up to the Moho.

UHP province remained attached to shallower crust in the subducted slab during exhumation.

\section{Geologic Setting}

[7] The Western Gneiss Region (WGR, Figure 2) forms the high-pressure core of the Scandinavian Caledonides, which grew from closure of the Iapetus Ocean and collision between the Baltica (including Norway) and Laurentia (including Greenland) continental plates during Ordovician to Devonian time [Hossack and Cooper, 1986]. Baltica was overthrust by a series of thin, areally extensive thrust sheets derived from Laurentian and oceanic domains (Uppermost and Upper Allochthons) and the outermost Baltica margin (Middle and Lower Allochthons) [Roberts and Stephens, 2000; Hacker and Gans, 2005]. During the latest phase of the collision, the Scandian Orogeny (430-390 Ma), the leading edge of Baltica was subducted northwestward into the mantle beneath Laurentia where it reached UHP conditions $\left(600-820^{\circ} \mathrm{C}\right.$ and $2.8-3.9 \mathrm{GPa}$ [Wain, 1997; Cuthbert et al., 2000; Terry et al., 2000b], corresponding to burial depths of $100-140 \mathrm{~km}$.

[8] Following the shortening phase, the UHP core of the orogen was exhumed nearly isothermally to pressures of
0.5 GPa [Walsh and Hacker, 2004; Root et al., 2005] by a combination of pure shear and slip along large-scale, normal-sense shear zones [Fossen and Rykkelid, 1992; Andersen, 1998]. Late orogenic sedimentary basins of Latest Silurian to Devonian age (Figure 2) formed as a response to extension and transtension, and were filled with clastic material from the eroding mountain range.

[9] The UHP rocks crop out in three domal culminations along the coastal edge of the WGR that cover an aggregate area of $10,000 \mathrm{~km}^{2}$; these are mantled by high-pressure rocks (at least $1.5 \mathrm{GPa}$ ) covering a much larger area $(400 \mathrm{~km} \times 150 \mathrm{~km})$ (Figure 2). The southernmost and largest UHP culmination is in the Nordfjord-Stadlandet Peninsula area (Figure 2); this study focuses on the metamorphic transition from UHP rocks to HP rocks along the southern boundary of that area.

\section{Nordfjord UHP Domain}

[10] The Nordfjord area was one of the first UHP localities to be recognized worldwide, with the identification of coesite inclusions in clinopyroxene by Smith [1984]. Further discoveries of coesite and coesite pseudomorphs [Wain, 1997], and eclogite thermobarometry [Cuthbert et 


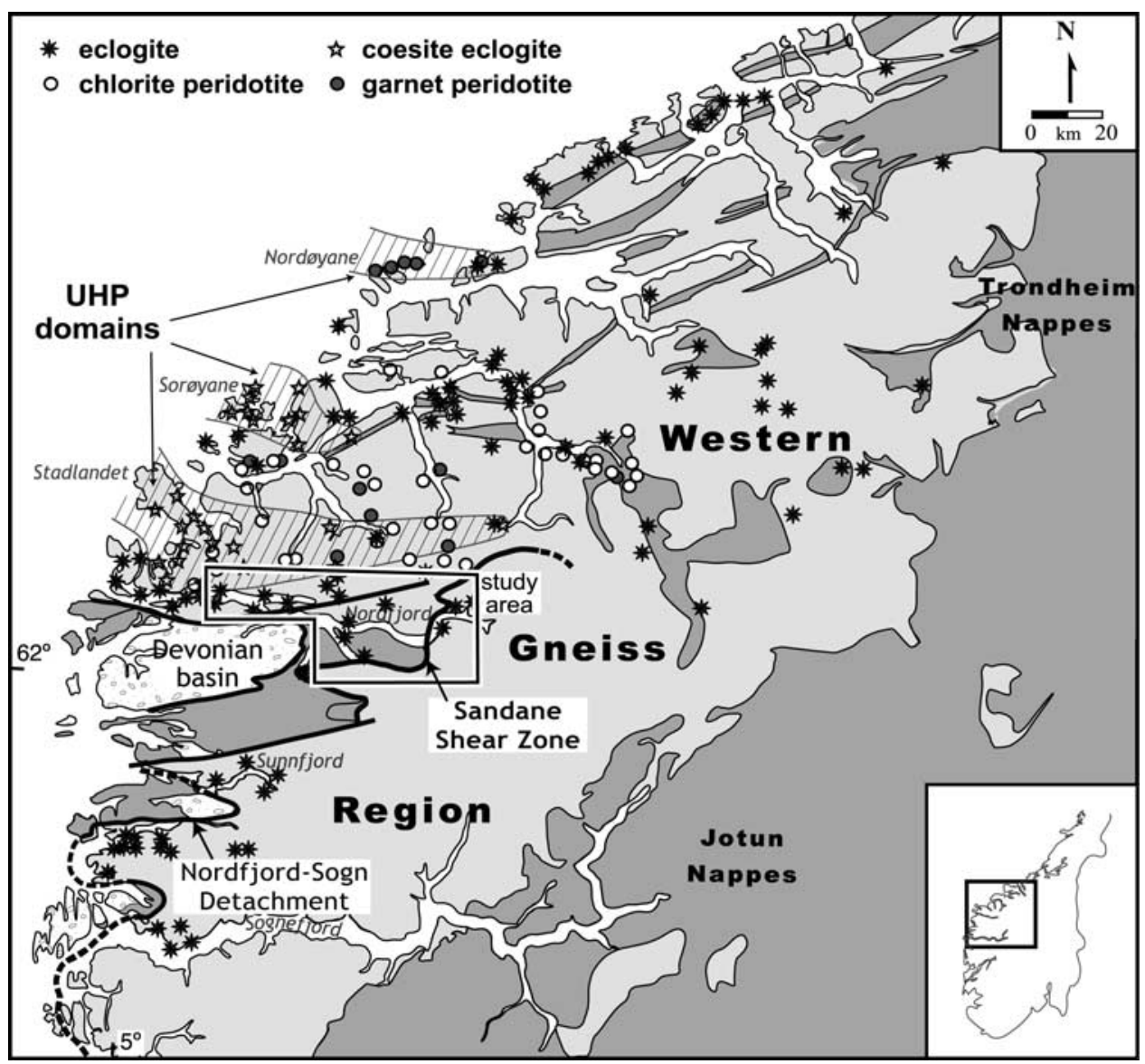

Figure 2. Eclogites and high-pressure peridotites along the seaboard of the Western Gneiss Region, Norway.

al., 2000; Labrousse et al., 2004] led to the delineation of the Nordfjord-Stadlandet UHP province [Root et al., 2005] (Figure 2). Rocks in the greater Nordfjord area have been assigned to the Western Gneiss Complex (WGC), the Lower Allochthon, and the Middle Allochthon units [Andersen et al., 1994; Wilks and Cuthbert, 1994] recognized elsewhere in the orogen [Roberts and Gee, 1985].

\subsection{Western Gneiss Complex}

[11] The parautochthonous Western Gneiss Complex (WGC) comprises fairly homogeneous medium grey, banded, quartz monzonitic, granodioritic and granitic gneiss with trondhjemitic and syenitic layers. Paragneiss, anorthosite, gabbro, megacrystic K-feldspar augen gneiss, mangerite and granulite are less common [Krabbendam and Wain, 1997; Bryhni, 2000a, 2000b]. The dominant mineralogy of these rocks is amphibolite facies: hornblende + epidote \pm garnet + biotite + plagioclase + K-feldspar + quartz. Eclogite occurs as rare meter-scale pods in the eastern part of the study area and as abundant meter- to decimeter-scale pods in the northern and western parts (Figure 3 ).

\subsection{Lower Allochthon}

[12] The Lower Allochthon, a strongly deformed unit above the WGC, includes medium- to coarse-grained quartzofeldspathic and calcareous schists (garnet + muscovite + biotite + epidote/zoisite + quartz + plagioclase + $\mathrm{K}$-feldspar \pm calcite) with local interlayered 10-50 m thick quartzite, decimeter-scale marble, garnet amphibolite, and rare hornblende-bearing eclogites. North of Nordfjord it thins and disappears, so that the WGC and the overlying Middle Allochthon are in direct contact.

\subsection{Middle Allochthon}

[13] The structurally highest unit, the Middle Allochthon (Figure 3), contains a 200-500 m thick basal section of hornblende and biotite-rich gneiss, anorthosite, metagabbro, megacrystic augen gneiss, and rare granulite and gabbronorite pods. These rocks are hosted within granitic, granodioritic, and augen gneiss that characterize the bulk of this unit. Eclogite appears north of Nordfjord and is not found farther south.

\section{Structural Geology}

[14] The structure of the greater Nordfjord area is defined by late orogenic, amphibolite- to greenschist-facies features, and is described in greater detail elsewhere [Krabbendam and Wain, 1997; Labrousse et al., 2004]; a brief summary is given here. The structural stack of Middle Allochthon/ 
$z$

$z$
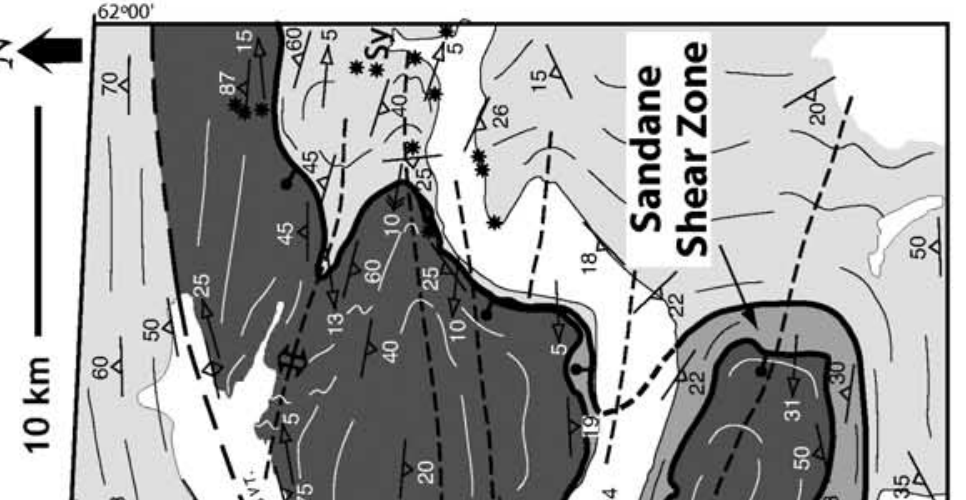

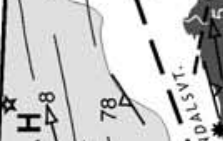
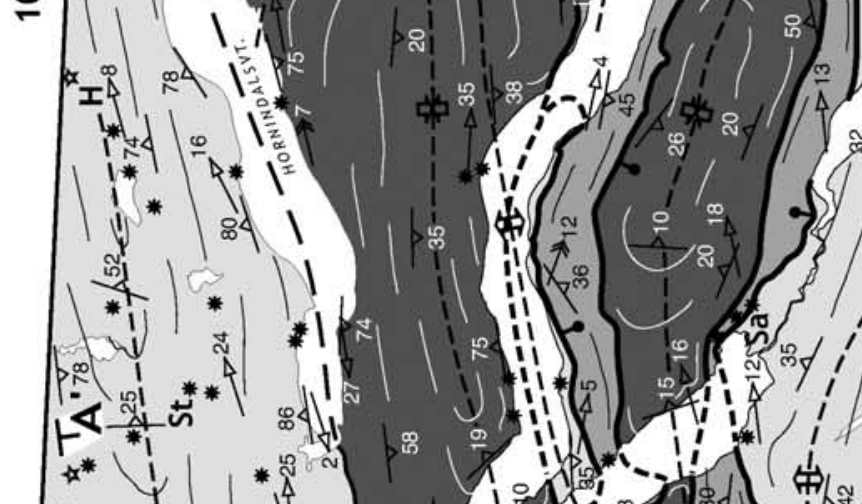

$$
\text { 争 }
$$

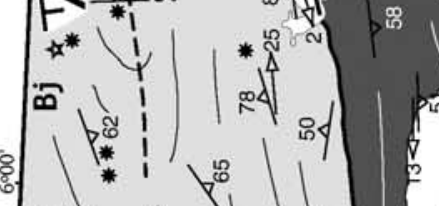

Jै
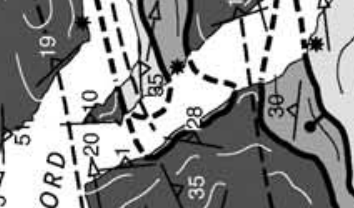

( )

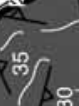

po-

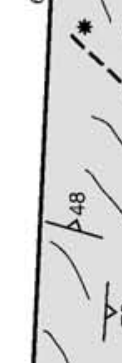

3
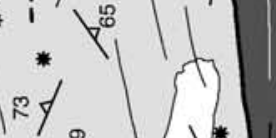

1.)

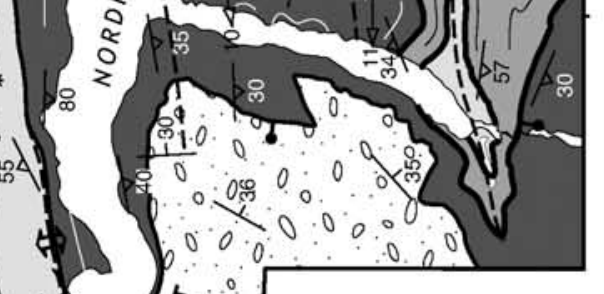

$\rightarrow$

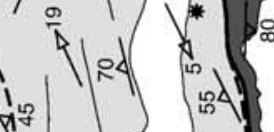

* $\int S W \int \begin{array}{lll}0 & 0 \\ 0 & 0 & 0 \\ 0 & 0 & 0\end{array}$
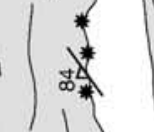

)
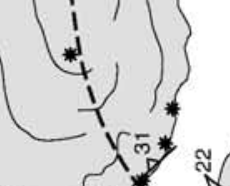

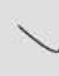
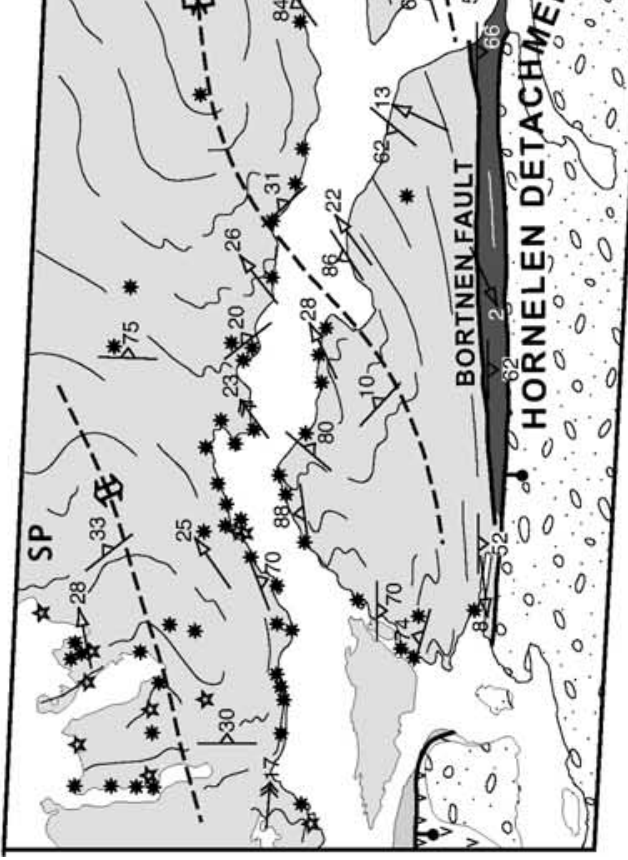

20.

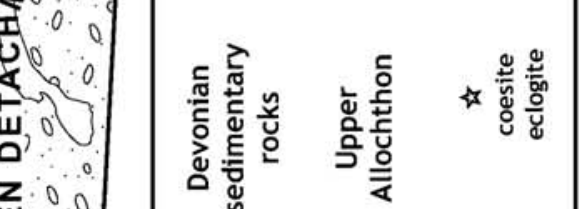

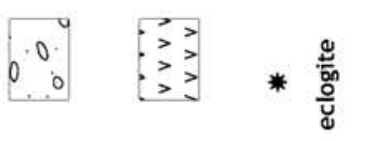

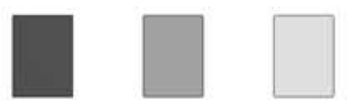

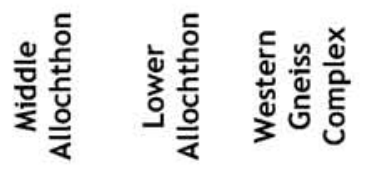

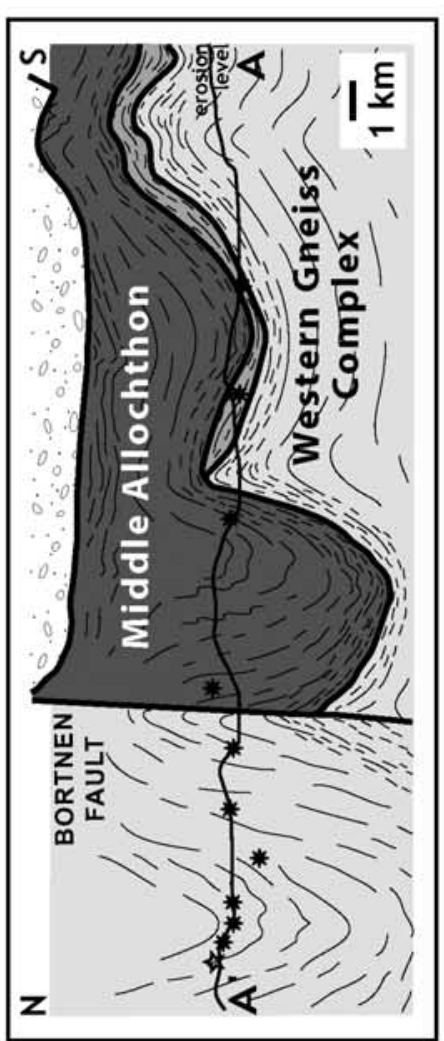

象 
Lower Allochthon/Western Gneiss Complex is overprinted by bulk E-W stretching and noncoaxial shear at amphibolitefacies conditions. A high-strain zone, the Sandane Shear Zone (SSZ), is concentrated within the Lower Allochthon, but extends $\sim 300 \mathrm{~m}$ down into the WGC and at least $500 \mathrm{~m}$ up into the Middle Allochthon (Figure 3); amphibolite- to greenschist-facies $\mathrm{S} / \mathrm{C}$ - and C'-type shear bands, $\sigma$ porphyroclasts, asymmetric boudins and small normal faults within the SSZ indicate top-to-west sense of movement. Late, kilometer-scale, open to tight, upright folds reorient the tectonostratigraphy and the amphibolite/greenschist-facies shear fabrics (Figure 3). The Middle Allochthon is truncated to the north against the Bortnen Fault, a late, brittle-ductile, left-lateral shear structure; mylonitic WGC rocks reappear on the north side of this fault.

[15] The SSZ is part of the Nordfjord-Sogn Detachment Zone (NSDZ), a system of west dipping extensional shear zones along the west coast that is generally considered responsible for exhumation of the (U)HP rocks [Andersen et al., 1991; Krabbendam and Dewey, 1998; Labrousse et al., 2004]. However, the SSZ cannot have accommodated profound exhumation, because eclogite is found throughout the shear zone, suggesting vertical displacement between units was $<10 \mathrm{~km}$.

\section{Eclogite Thermobarometry}

[16] Defining the extent and metamorphic conditions of a particular HP/UHP event relies upon recognition of index minerals such as coesite or diamond, or being able to recover peak pressures and temperatures from mineral assemblages in eclogite. Here we present thermobarometry for numerous eclogite bodies identified in the Nordfjord area; these rock types constitute $<1 \mathrm{vol} \%$ of the total rock mass, and judging from their disposition as trails of boudins, thin layers or small masses (up to decameters), were likely once mafic sheets or dikes emplaced within the continental quartzofeldspathic gneiss.

[17] The petrographic characteristics of 30 eclogite samples were studied. Mineral compositions were measured from 15 of these on the Cameca SX-50 electron microprobe at the Department of Geological Sciences, University of California, Santa Barbara, with an accelerating voltage of $15 \mathrm{kV}$, a beam current of $15 \mathrm{nA}$, a beam size of $2 \mu \mathrm{m}$, and natural and synthetic mineral standards (Table 1).

[18] Fifteen eclogites retain phengite, allowing estimation of pressure via the net transfer reaction diopside + muscovite $=$ pyrope + grossular + celadonite [Waters and Martin, 1993]. This reaction has a gentle Clapeyron slope, is $\mathrm{H}_{2} \mathrm{O}$ conservative, and does not involve iron, thus eliminating the effects of uncertainties in mineral ferrous/ferric ratios. The $\mathrm{P}-\mathrm{T}$ position of this reaction was calculated by two methods: (1) THERMOCALC version 3.25 software with the May 2001 thermodynamic data set and activities determined by the program A-X [Holland and Powell, 1998], which uses the Newton and Haselton [1981] model for garnet activities; and (2) the formulation of Krogh Ravna and Terry [2004], which uses the Ganguly et al. [1996] garnet activity model. Temperatures were computed with Krogh Ravna's [2000] calibration of $\mathrm{Fe}-\mathrm{Mg}$ exchange between garnet and omphacite, estimating ferric iron by charge balance using the method of Stipska and Powell [2005]. The presence of kyanite in two eclogites (Y1614B, Y1616G) also permitted use of the diopside + kyanite $=$ pyrope + grossular + quartz/coesite equilibrium $[$ Krogh Ravna and Terry, 2004], which has the same advantages as above, plus it is unaffected by uncertainties with white mica activity models.

[19] Our P-T calculations are subject to the usual uncertainties, including (1) analytical imprecision in measuring standards and unknowns; (2) uncertainties in thermodynamic data; (3) uncertainties in activity models; (4) disequilibrium (e.g., compositional zoning, etc); and (5) ferrous/ferric ratio. Uncertainties reported by THERMOCALC include the effects of $1-3$, and are generally $\pm 0.2 \mathrm{GPa}$ and $\pm 60^{\circ} \mathrm{C}$ (see Table 2). Judicious selection of mineral analyses via careful petrography can reduce the influence of 4). Our choice of mineral analyses for thermobarometry follows the approach used by other eclogite studies in the WGC [Cuthbert et al., 2000], the Dabie Shan [Carswell et al., 1997] and the Dora Maira [Nowlan et al., 2000]: maximum pressures were calculated from near-rim garnet analyses with high $a_{\text {pyrope }} a_{\text {grossular }}^{2}$ component, phengites with high celadonite component and omphacites with high jadeite content. We estimate the sample-specific uncertainty in $\mathrm{P}$ and $\mathrm{T}$ this introduces, by choosing a range of mineral compositions that fit these criteria, at an additional $\pm 0.1 \mathrm{GPa}$ and $\pm 50^{\circ} \mathrm{C}$. Ferrous/ferric ratios in minerals are potentially the most serious problem affecting thermobarometry of eclogites, leading, most notably, to calculated temperatures that may be inaccurate by more than $100^{\circ} \mathrm{C}$ (see review by Hacker [2006]). Steps toward calculating the magnitude of this uncertainty were presented by Stipska and Powell [2005]; we followed their approach in this paper and then propagated this uncertainty into the calculated pressure. The pressure determined by THERMOCALC from the intersection of the garnet-clinopyroxene thermometer (dependent on $\mathrm{Fe}^{2+} / \mathrm{Fe}^{3+}$ ) with the garnet-clinopyroxenephengite-quartz equilibria (i.e., a kyanite-free eclogite) deviates from the intersection of garnet-clinopyroxenephengite-quartz and garnet-clinopyroxene-kyanitequartz equilibria (independent on $\mathrm{Fe}^{2+} / \mathrm{Fe}^{3+}$ ) determined using Krogh Ravna and Terry's [2004] results by $<0.2 \mathrm{GPa}$ for UHP eclogites worldwide [Hacker, 2006]. Finally, it is important to note that, for the purposes of comparing $\mathrm{P}-\mathrm{T}$ determinations for a suite of eclogites, the

Figure 3. Geological map and N-S cross section of the Nordfjord area, from the present study, Krabbendam and Wain [1997], Bryhni [2000a, 2000b], and Bryhni and Lutro [2000]. Place names are Bj, Bjørkedalen; H, Heggjadalen; Sa, Sandane; SP, Stadlandet Peninsula; St, Stigedalen; Sy, Stryn. 


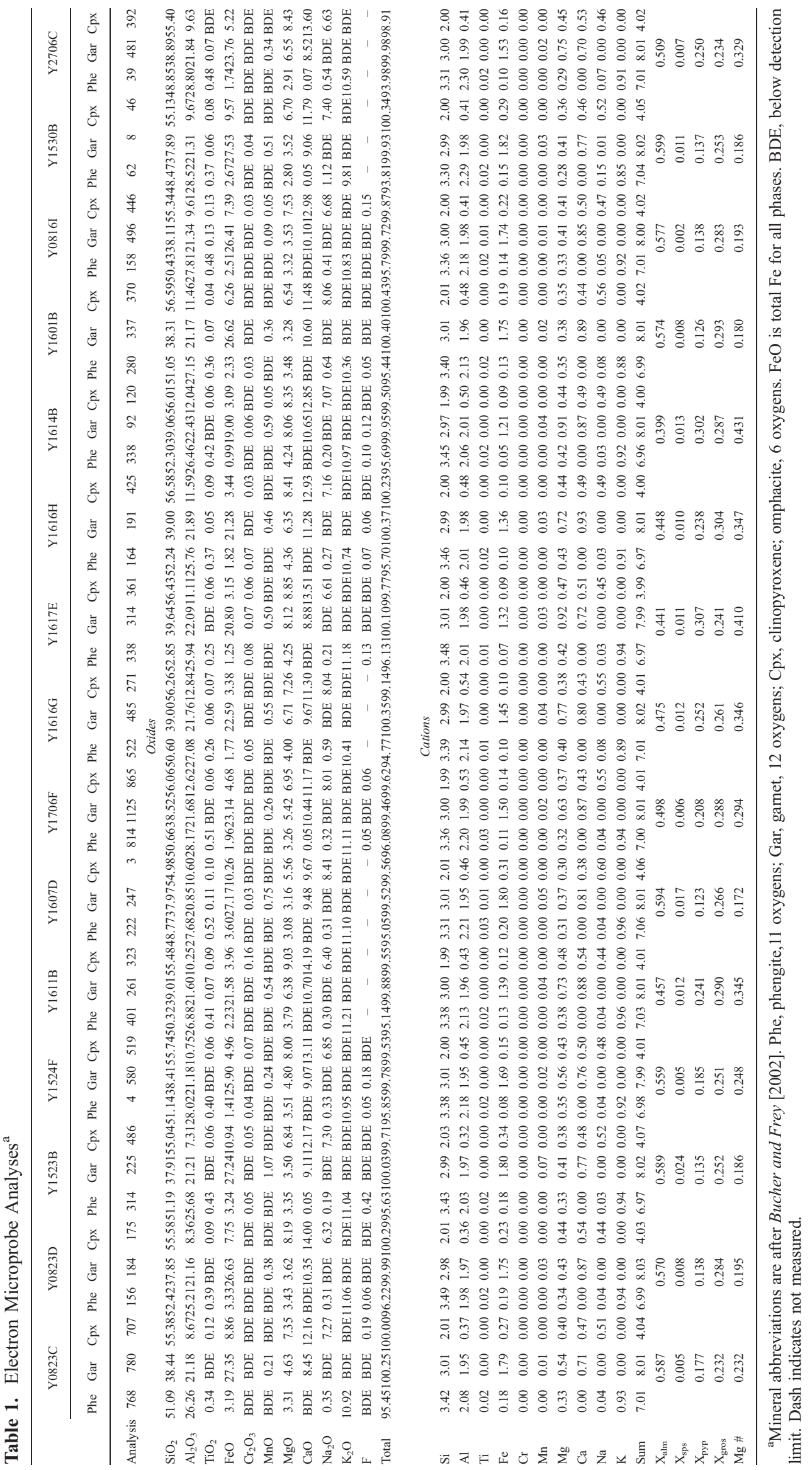


Table 2. Results of Garnet-Omphacite-Phengite ( \pm Kyanite) Thermobarometry

\begin{tabular}{|c|c|c|c|c|c|}
\hline Sample & $\mathrm{UTM},{ }^{\mathrm{a}} \mathrm{mE} / \mathrm{mN}$ & $\mathrm{T},{ }^{\mathrm{b}}{ }^{\circ} \mathrm{C}$ & $\mathrm{P}^{\mathrm{b}}{ }^{\mathrm{GPa}}$ & $\mathrm{T},{ }^{\mathrm{c}} \mathrm{C}$ & $\mathrm{P},{ }^{\mathrm{c}} \mathrm{GPa}$ \\
\hline \multicolumn{6}{|c|}{ Western Gneiss Complex } \\
\hline Y0823C & $74950 / 62110$ & $590 \pm 80$ & $2.46 \pm 0.18$ & $597 \pm 56$ & $2.31 \pm 0.20$ \\
\hline Y0823D & $75395 / 62273$ & $610 \pm 88$ & $2.72 \pm 0.19$ & $629 \pm 57$ & $2.49 \pm 0.19$ \\
\hline Y1523B & $77886 / 63853$ & $597 \pm 80$ & $2.47 \pm 0.19$ & $605 \pm 56$ & $2.38 \pm 0.18$ \\
\hline $\mathrm{Y} 1524 \mathrm{~F}$ & $77938 / 66767$ & $600 \pm 92$ & $2.43 \pm 0.17$ & $612 \pm 58$ & $2.27 \pm 0.19$ \\
\hline Y1611B & $47764 / 69805$ & $618 \pm 80$ & $2.81 \pm 0.18$ & $631 \pm 63$ & $2.71 \pm 0.18$ \\
\hline Y1607D & $38890 / 66866$ & $663 \pm 81$ & $2.55 \pm 0.23$ & $644 \pm 65$ & $2.47 \pm 0.22$ \\
\hline Y1706F & $16742 / 68621$ & $688 \pm 81$ & $2.78 \pm 0.22$ & $698 \pm 69$ & $2.80 \pm 0.19$ \\
\hline Y1616G & $30337 / 69292$ & $648 \pm 80$ & $2.91 \pm 0.24$ & $700 \pm 70$ & $2.98 \pm 0.19$ \\
\hline Y1616G $(+k y)^{d}$ & & $655 \pm 65$ & $2.92 \pm 0.32$ & - & - \\
\hline Y1617E & $23830 / 69230$ & $702 \pm 98$ & $3.19 \pm 0.21$ & $791 \pm 77$ & $3.10 \pm 0.18$ \\
\hline Y1616H & 29282/69206 & $685 \pm 113$ & $3.32 \pm 0.31$ & $692 \pm 75$ & $3.32 \pm 0.18$ \\
\hline Y1614B & $62100 / 77700$ & $740 \pm 108$ & $3.40 \pm 0.28$ & $747 \pm 87$ & $3.35 \pm 0.18$ \\
\hline Y1614B $(+k y)^{d}$ & & $716 \pm 65$ & $3.35 \pm 0.32$ & - & - \\
\hline \multicolumn{6}{|c|}{ Lower Allochthon } \\
\hline Y1601B & $48229 / 57111$ & $596 \pm 85$ & $2.52 \pm 0.22$ & $578 \pm 55$ & $2.49 \pm 0.20$ \\
\hline \multicolumn{6}{|c|}{ Middle Allochthon } \\
\hline Y0816I & $51321 / 60734$ & $639 \pm 81$ & $2.50 \pm 0.17$ & $645 \pm 60$ & $2.26 \pm 0.19$ \\
\hline Y1530B & $72574 / 63864$ & $589 \pm 98$ & $2.10 \pm 0.18$ & $600 \pm 58$ & $1.98 \pm 0.20$ \\
\hline Y2706C & $76812 / 70787$ & $596 \pm 80$ & $2.17 \pm 0.13$ & $631 \pm 64$ & $2.06 \pm 0.20$ \\
\hline
\end{tabular}

${ }^{\mathrm{a}}$ UTM map grid coordinates are zone 32, map sheets 1318 (I, III, IV), 1218 (I, II, IV), 1118 (I); mE/mN, meters east/meters north.

${ }^{\mathrm{b}}$ Calculated using garnet-omphacite-phengite ( \pm kyanite) formulations of Krogh Ravna and Terry [2004], employing clinopyroxene ferrous/ferric recalculation of Stipska and Powell [2005]; P and T errors include ferrous/ferric uncertainty and $\pm 0.1 \mathrm{GPa} / 50^{\circ} \mathrm{C}$ disequilibrium uncertainty.

${ }^{\mathrm{c}}$ Garnet-omphacite-phengite results calculated by mode 1 of THERMOCALC v3.25 software [Holland and Powell, 1998]; errors are $1 \sigma$ reported by THERMOCALC $\left( \pm 0.1 \mathrm{GPa} / 50^{\circ} \mathrm{C}\right.$ systematic error for disequilibrium is not included).

${ }^{\mathrm{d}}$ Kyanite-bearing equilibria using formulations and P-T uncertainties of Krogh Ravna and Terry [2004].

main thrust of this paper, uncertainties in thermodynamic data and (to a lesser extent) activity models are irrelevant.

\subsection{Western Gneiss Complex}

[20] Eclogite is rare in the southern and eastern parts of the WGC in the study area; the main localities are scattered near Stryn, and single pods were found west and north of Sandane (Y0823C, Y0823D, Y1523B, Y1524F, Figure 3). These lenses are small $(1-30 \mathrm{~m})$, fine-grained $(<2 \mathrm{~mm})$, and invariably massive. They contain $25-35 \%$ garnet in a matrix of chiefly unoriented omphacite $(17-62 \%)$ and primary hornblende $(4-20 \%)$; most contain between $2-$ $9 \%$ phengite, and only one lacks quartz. Rutile and biotite are accessory phases. Garnet occurs as two textural varieties: volumetrically minor scattered larger grains up to $2 \mathrm{~mm}$, and more abundant smaller idioblasts $(200-500 \mu \mathrm{m})$ that form aggregates, trails or networks (Figure 4). Larger garnet is hypidioblastic and often contains cores with numerous inclusions of hornblende, epidote, plagioclase, and quartz; most small idioblastic garnets are inclusion free. These small idioblasts also form mantles around larger single garnet cores, indicating two separate garnet-growth events. Grain boundaries between garnet rims, omphacite and primary matrix hornblende are locally pristine, suggesting local equilibrium. A few samples contain ragged grains of epidote or clinozoisite, mostly present as inclusions, or finegrained clots inferred to be retrograde.
[21] Partial to complete retrogression of the peak parageneses is common: omphacite has broken down to symplectites of diopside + plagioclase or amphibole + plagioclase, and phengite has recrystallized to biotite + plagioclase symplectite. Resorption of garnet is identifiable by rims enriched in $\mathrm{Mn}$, or partial replacement by hornblende + biotite + plagioclase.

[22] The major element chemistry of garnet in these eclogites varies as a function of bulk composition and zoning: Ca increases rimward in some samples, but in most grains it decreases or varies inconsistently between $18-$ $32 \mathrm{~mol} \%, \mathrm{Mg}$ ranges between $8-22 \mathrm{~mol} \%$, Fe is generally between $50-60 \mathrm{~mol} \%$, and $\mathrm{Mn}$ is consistently low $(<2 \mathrm{~mol} \%)$. Most small garnet idioblasts are homogeneous or weakly zoned and have low $\mathrm{Mn}$, low $\mathrm{Ca}$, and high $\mathrm{Mg} \#$ compositions that also characterize the rims of the larger garnets. Diffusional modification of garnet is inferred to have been minor to moderate, based on the survival of steep compositional zoning and thin Mn-enriched rims. Phengite and omphacite generally have homogeneous or spatially heterogeneous compositions, suggesting domainal recrystallization. The highest jadeite contents of the omphacites $(45-52 \mathrm{~mol} \%)$ and the highest $\mathrm{Si}$ contents of the phengites (3.4 per formula units (pfu)) are chiefly found in grain cores.

[23] These eclogites all share a prograde evolution from a preexisting amphibolite-facies mineral assemblage to an eclogitic paragenesis of garnet + omphacite + phengite + rutile. This history is manifest in (1) numerous amphibolite- 

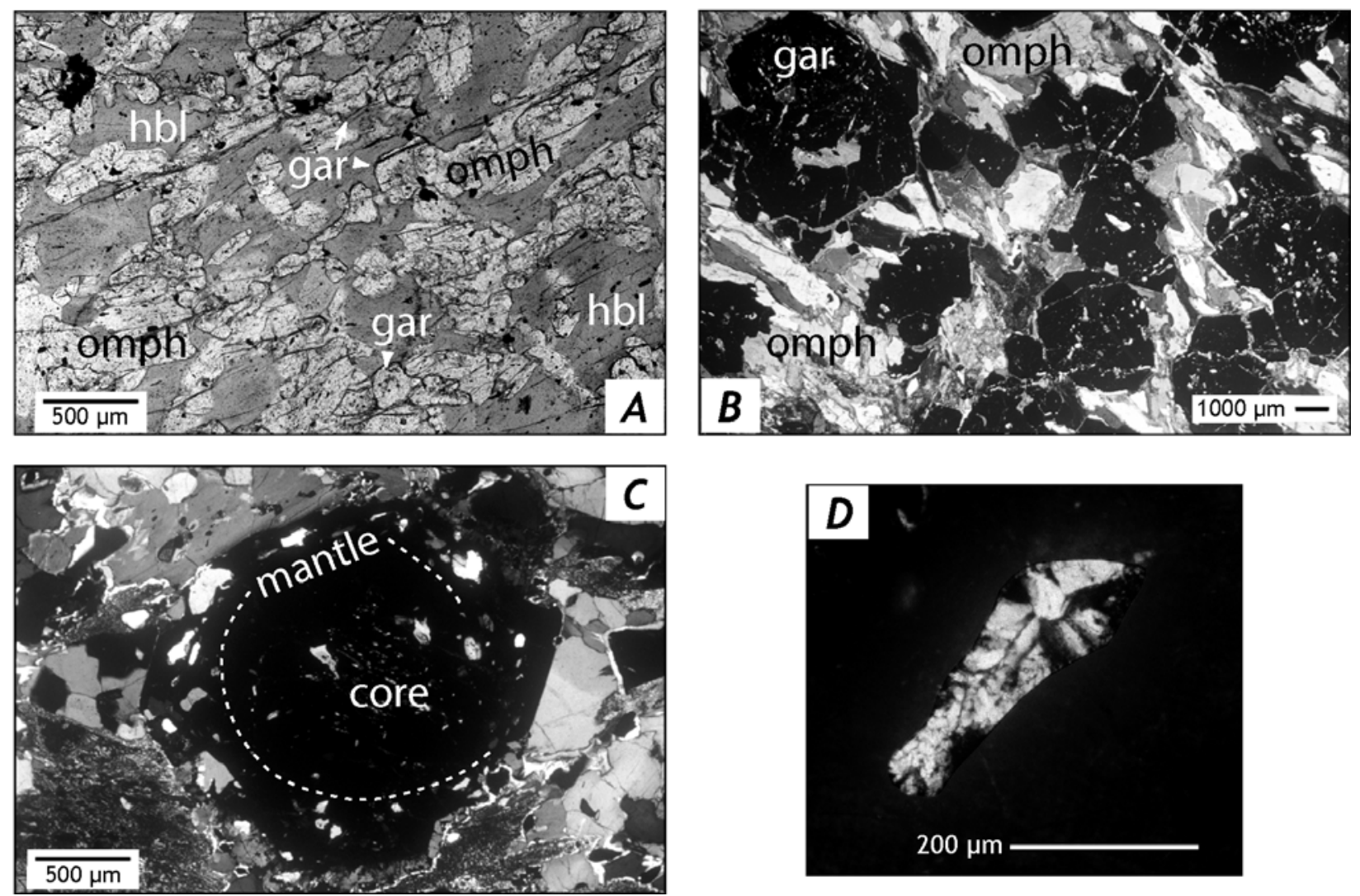

Figure 4. Representative photomicrographs. (a) Small garnet (gar) and omphacite (omph) grains growing within large hornblende (hbl) grains in WGC quartz eclogite (Y1613D2), PPL; (b) coarse, blastic, near-UHP eclogite containing garnet and omphacite (Y1611N), XPL; (c) garnet growth stages with small (core) or large (mantle) inclusions in Middle Allochthon quartz eclogite (Y1530B), PPL; and (d) a coesite pseudomorph of polycrystalline quartz included in zoisite in eclogite Y1614B, XPL.

facies inclusions in garnet cores (the same minerals are rare to absent in the matrix); (2) small garnet and omphacite growing around and through older large amphibole grains (Figure 4a); (3) preserved major element growth zoning in garnet, partially flattened by diffusion (e.g., rimward in-

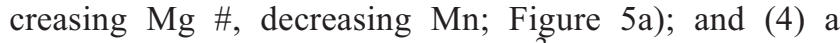
positive correlation between $\mathrm{a}_{\text {pyrope }} \mathrm{a}_{\text {grossular }}^{2}$ and $\mathrm{Mg} \#$ in garnet. These changes are compatible with mineral growth during increasing pressure and temperature. $\mathrm{P}-\mathrm{T}$ estimates from these four eclogites in the southeastern part of the study area are equivalent within uncertainty at $2.2-2.5 \mathrm{GPa}$ and $593-617^{\circ} \mathrm{C}$ (Table 2 and Figure 6).

[24] Eclogite bodies are larger, fresher and more abundant north of the Bortnen Fault. Relict primary hornblende is present near the fault but disappears northward, clinozoisite replaces epidote in peak assemblages, and textures become coarse and blastic (Figure 4b). Mineralogy is dominated by subequal amounts of garnet and omphacite, with minor phengite $(<10 \%)$; two kyanite-bearing eclogites were identified in the UHP province $(<5 \% \mathrm{ky})$, and zoisite or dolomite are significant constituents in a few samples. A new UHP eclogite locality with polycrystalline quartz inclusions (Y1614B) has been identified in Heggjadalen (H: Figure 3). HP eclogite in the southeast of the study area (e.g., Y1607D, Y1706F) is generally medium grained $(<2 \mathrm{~mm})$, whereas UHP eclogite is mostly medium to coarse grained ( $2 \mathrm{~mm}$ up to $1 \mathrm{~cm}$ ), with rare fine-grained examples $(<500 \mu \mathrm{m}$ : Y1617E, Y1616G). Eclogite in the far north of the study area has coarse, xenoblastic, homogeneous assemblages similar to those described for the classic UHP localities on Stadlandet [Smith, 1988; Wain, 1997]. Some eclogites have a foliation and/or lineation defined by omphacite, phengite or zoisite, but others are massive, indicating no consistent strain at eclogite facies.

[25] Mineral zoning is subdued yet still recognizable in samples closer to the Bortnen Fault (Y1611B; Y1607D; Figure 5c). Larger garnets in Y1607D and Y1706F preserve continuous rimward increase in $\mathrm{Mg}(10-20 \mathrm{~mol} \%)$, whereas $\mathrm{Ca}$ declines steadily or varies inconsistently. UHP eclogites (Y1617E, Y1614B, Y1616H) generally have homogeneous minerals (Figure 5d); omphacite $(\mathrm{Na}=43-55 \mathrm{~mol} \%)$ and phengite $(\mathrm{Si}=3.24-3.48 \mathrm{pfu})$ are overprinted by retrograde zoning toward grain edges. 
a) WGC eclogite-Y0823C

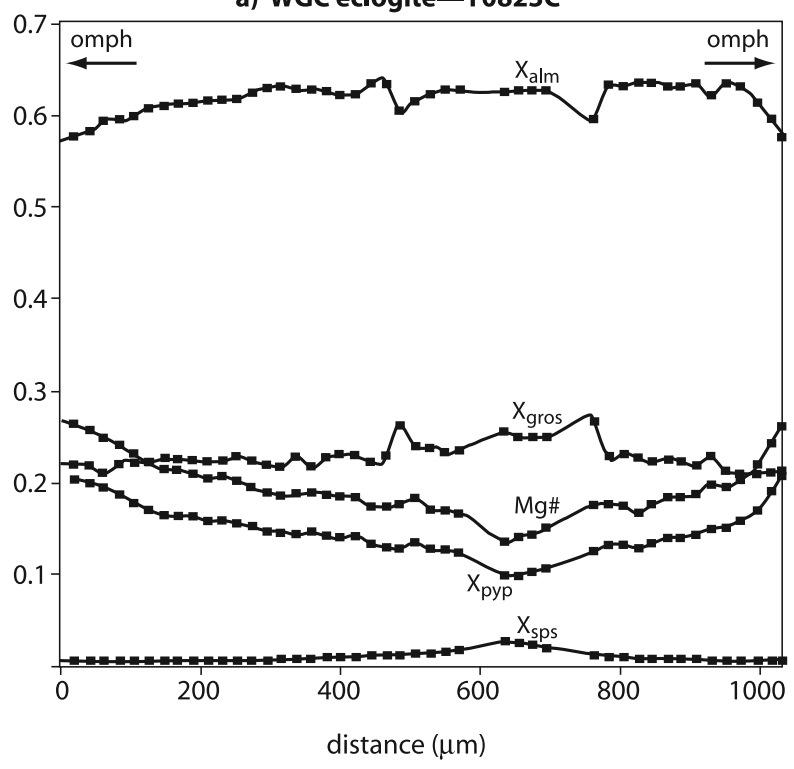

c) WGC transitional eclogite-Y1611B

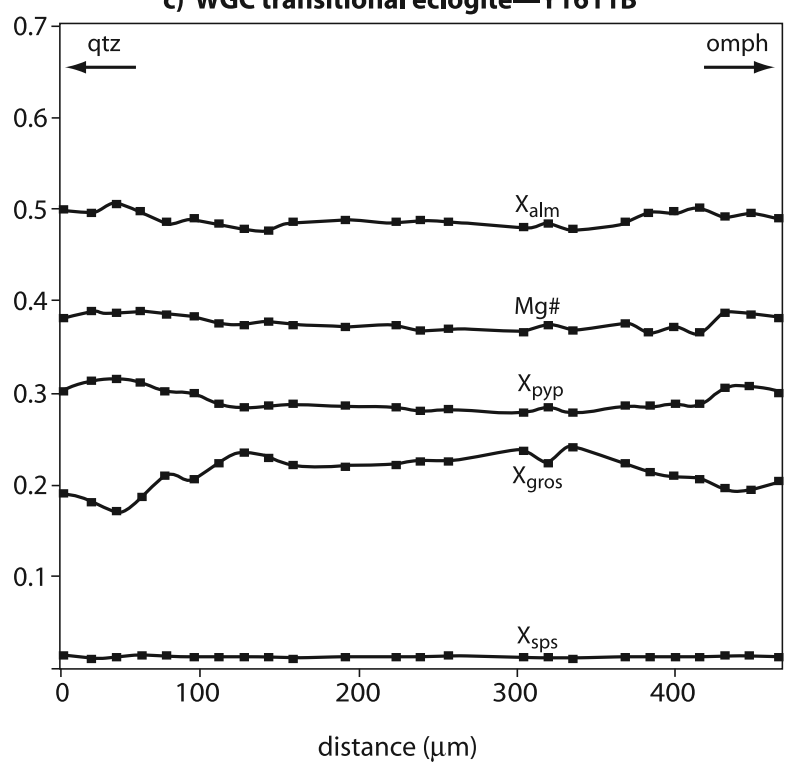

b) Middle Allochthon quartz eclogite-Y1530B

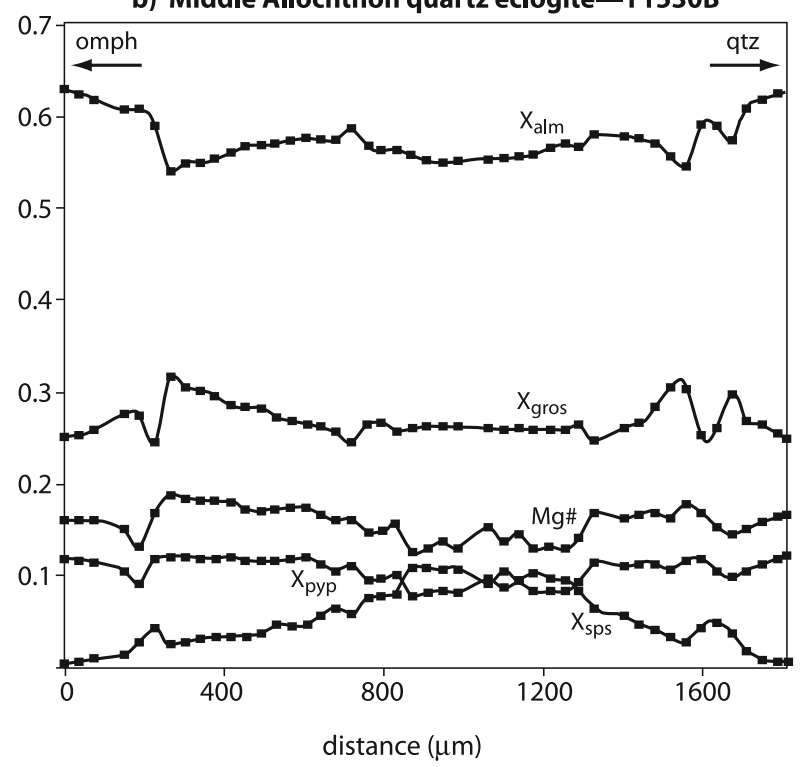

d) WGC UHP eclogite-Y1614B

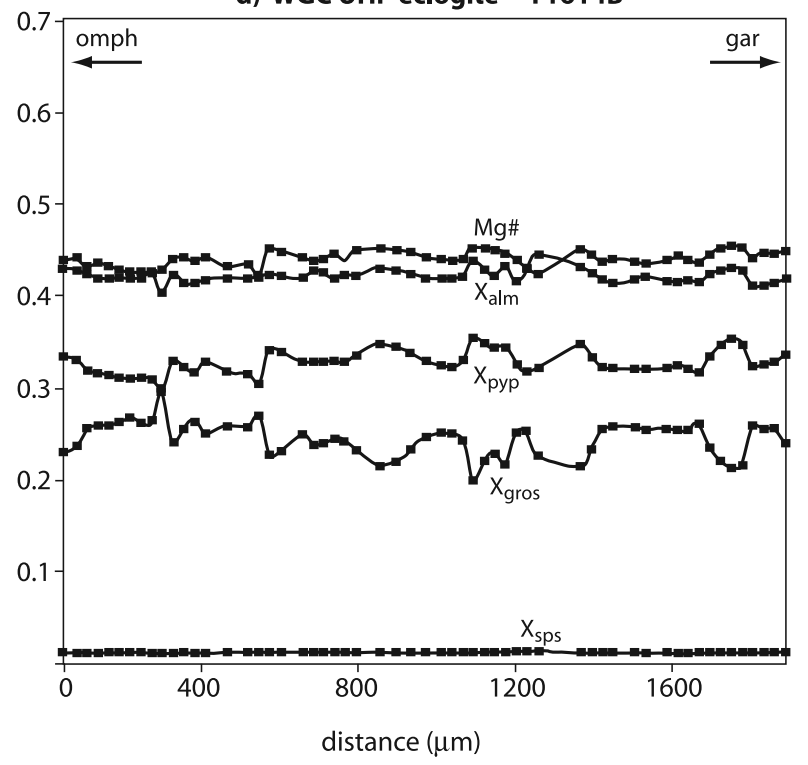

Figure 5. Eclogite garnet compositional profiles. (a) Prograde zoning in Western Gneiss Complex eclogite (Y0823C); (b) modified prograde zoning in Middle Allochthon eclogite (Y1530B); (c) nearly homogeneous garnet in transitional eclogite Y1611B; and (d) homogeneous garnet in UHP eclogite Y1614B.

[26] These textural observations are supported by garnetclinopyroxene-phengite-quartz thermobarometry, which increases steadily in peak pressure and temperature northnorthwestward, from $\sim 2.5 \mathrm{GPa} / 640^{\circ} \mathrm{C}$ adjacent to the Bortnen Fault to $>3 \mathrm{GPa} / 700-750^{\circ} \mathrm{C}$ in the UHP domain at the northern and western edges of the study area (Figures 6 and 7 and Table 2). The temperature increase northward is reflected in progressive erasure of garnet growth zoning, and the disappearance of primary amphibole beyond pressures of $2.5 \mathrm{GPa}$ is consistent with synthesis experiments by Poli [1993]. Our calculated garnet-clinopyroxene-phengite-quartz pressures could be slight overestimates, as suggested by the observation that several samples with indicated pressures up to $0.5 \mathrm{GPa}$ greater than the lower stability limit of coesite lack evidence for the current or former presence of this phase (Figure 6), although these samples also lack significant quartz. Garnet-kyanite- clinopyroxene-phengite-quartz thermobarometry results in pressures and temperatures for two kyanite eclogites (Y1614B and Y1616G) that identical within error to garnet-clinopyroxene-phengite-quartz estimates for the same sample (Table 2). 


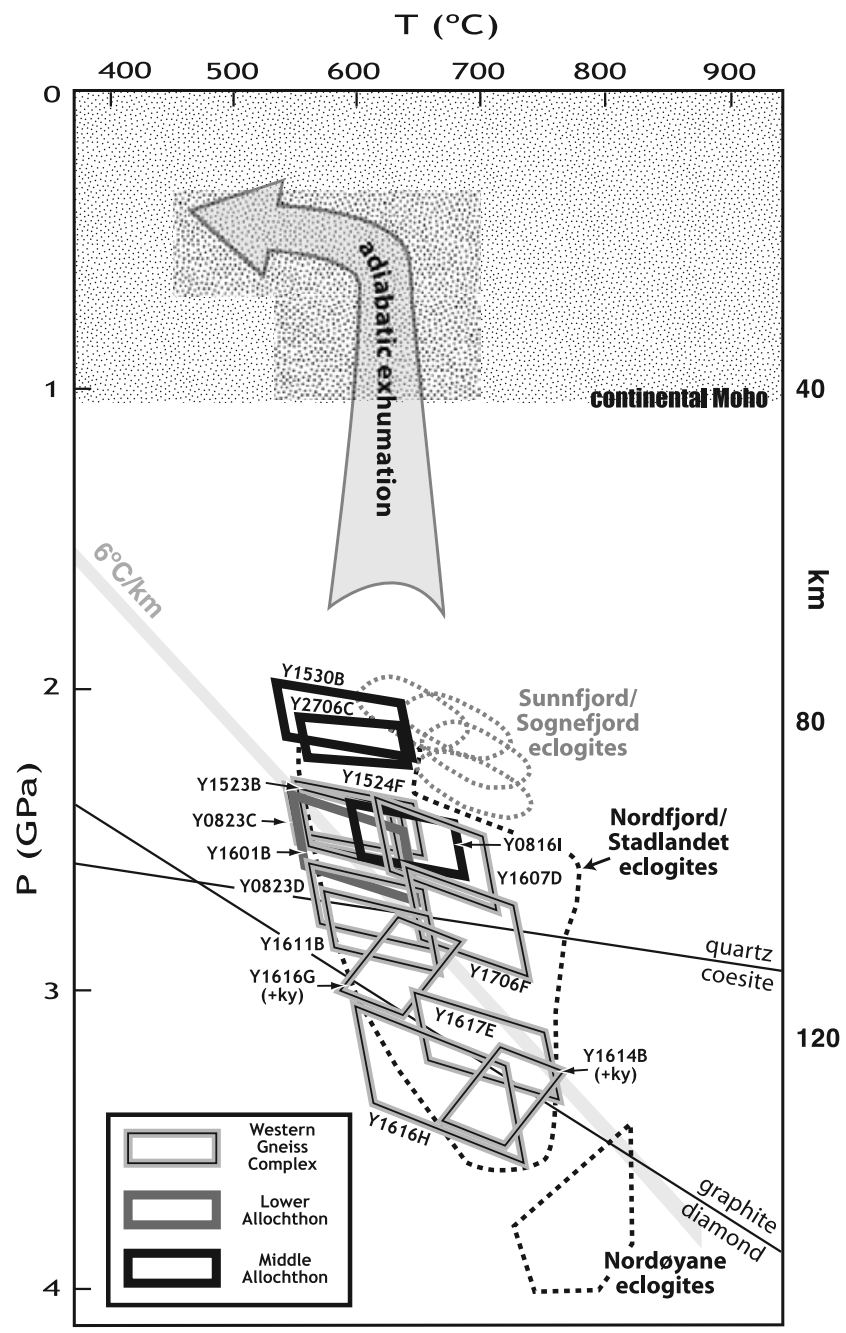

Figure 6. Eclogites from the Nordfjord area range in pressure and temperature from $\sim 2 \mathrm{GPa} / 600^{\circ} \mathrm{C}$ to $3.5 \mathrm{GPa} /$ $800^{\circ} \mathrm{C}$, similar to eclogites elsewhere in the Western Gneiss Complex. A subsequent amphibolite-facies overprint occurred during decompression from $\sim 1.5$ to $\sim 0.5 \mathrm{GPa}$. Solid parallelograms show P-T data calculated from Krogh Ravna and Terry [2004] formulations (see Table 2); uncertainties are shown at $\pm 0.5 \sigma$ for clarity. Dotted lines are from other studies: Sognefjord/Sunnfjord [Hacker et al., 2003; Labrousse et al., 2004], Nordfjord-Stadlandet [Cuthbert et al., 2000; Krogh Ravna and Terry, 2004], and Nordøyane [Terry et al., 2000b].

\subsection{Lower Allochthon}

[27] Eclogite is rare in the Lower Allochthon: only two localities are known in the Sandane area (Figure 3). These are small mafic bodies $(<5 \mathrm{~m})$ and occur within calc-schist and associated quartzite. One, Y1601B, has a foliation defined by the preferred orientation of omphacite ( $\sim 25$ vol $\%)$, hornblende $(\sim 18$ vol $\%)$, white mica $(\sim 8$ vol $\%)$ and minor zoisite. The eclogite-facies phases are invariably fine-grained $(<250 \mathrm{um})$ and abundant: omphacite occurs in large bundles of elongate grains, and garnet ( $\sim 33$ vol \%) is hypidioblastic. Mutual, unreacted contacts between blue-green hornblende and omphacite suggest local equilibrium, and relict poikiloblastic plagioclase riddled with omphacite, garnet and zoisite inclusions indicate prograde growth of an eclogite-facies paragenesis from an amphibolite-facies protolith.

[28] Mineral zoning in Lower Allochthon eclogite is similar to that in WGC quartz eclogite. In garnet, Mn humps are generally subdued or minor, and $\mathrm{Mg} \#$ increases toward the rims of many grains $(8-17 \mathrm{~mol} \%)$, whereas $\mathrm{Ca}$ declines at the highest $\mathrm{Mg}$ \#. The $\mathrm{Mg}$ \# and celadonite components of phengite are highest in grain cores $(\mathrm{Si}=$ $3.33-3.41 \mathrm{pfu})$. Sodium increases rimward (49-55 mol \%) in some larger omphacite grains $(600 \mu \mathrm{m})$ to values consistent with the cores of younger, smaller omphacites; these smaller grains then show a rimward increase in $\mathrm{Mg} \#$ and decrease in $\mathrm{Na}$. Coarse poikiloblastic amphibole decreases in $\mathrm{Mg}$ \# rimward, accompanied by increasing edenite substitution. A maximum pressure of $2.5 \mathrm{GPa}$ at $597^{\circ} \mathrm{C}$ was calculated for eclogite Y1601B (Table 2 and Figure 6).

\subsection{Middle Allochthon}

[29] Mafic rocks in the Middle Allochthon grade from high-pressure amphibolite south of the fjord, into quartz eclogite north of the fjord (Figure 7). The high-pressure amphibolite-facies assemblages are in the anorthositic gabbro unit south of Nordfjord (Sandane area), where mafic rocks consist of garnet, hornblende, biotite, epidote/clinozoisite, ilmenite, albite and quartz. Lower strain lenses in this zone preserve garnet amphibolite and megacrystic augen gneiss with fine-grained coronae of garnet + hornblende developed between relict clinopyroxene and ternary feldspar. Zoning in garnet and hornblende is well preserved and indicates prograde metamorphism.

[30] The eclogite-in isograd, defined by the appearance of omphacite in garnet-bearing mafic rocks at the expense of albite and hornblende, is not marked by any structure. This isograd runs across inner Nordfjord and is cut by the SSZ to the east (Figure 7). Eclogite bodies closest to the lower contact of the Middle Allochthon (Y0816I, Y1530B) are meter-scale, medium-grained $(<2 \mathrm{~mm})$, and strongly retrogressed. Omphacite grains grow across a partially preserved amphibolite-facies fabric. Phengite is rare and usually retrogressed to biotite + plagioclase symplectite. Most garnet cores are rich in tiny inclusions of quartz, titanite and epidote, and mantles of larger garnets $(1-3 \mathrm{~mm})$ have abundant larger (up to $100 \mu \mathrm{m}$ ) inclusions of epidote, amphibole, and quartz (Figure 4c). Small idiomorphic garnets are generally free of larger inclusions.

[31] Zoning in these eclogites (Y0816I, Y2706C, Y1530B; Figure 5b) suggests prograde growth, modified by some diffusion. Manganese decreases from core to rim in most garnets (7 to $<1 \mathrm{~mol} \%$ ); a couple of grains also contain an abrupt Mn spike at the core/mantle contact (Figures $4 c$ and $5 b$ ), suggesting an intermediate period of garnet resorption. The preservation of the Mn spikes demonstrates limited volume diffusion, but small idioblasts ( $<300$ um) are generally homogeneous. The Mn decrease 


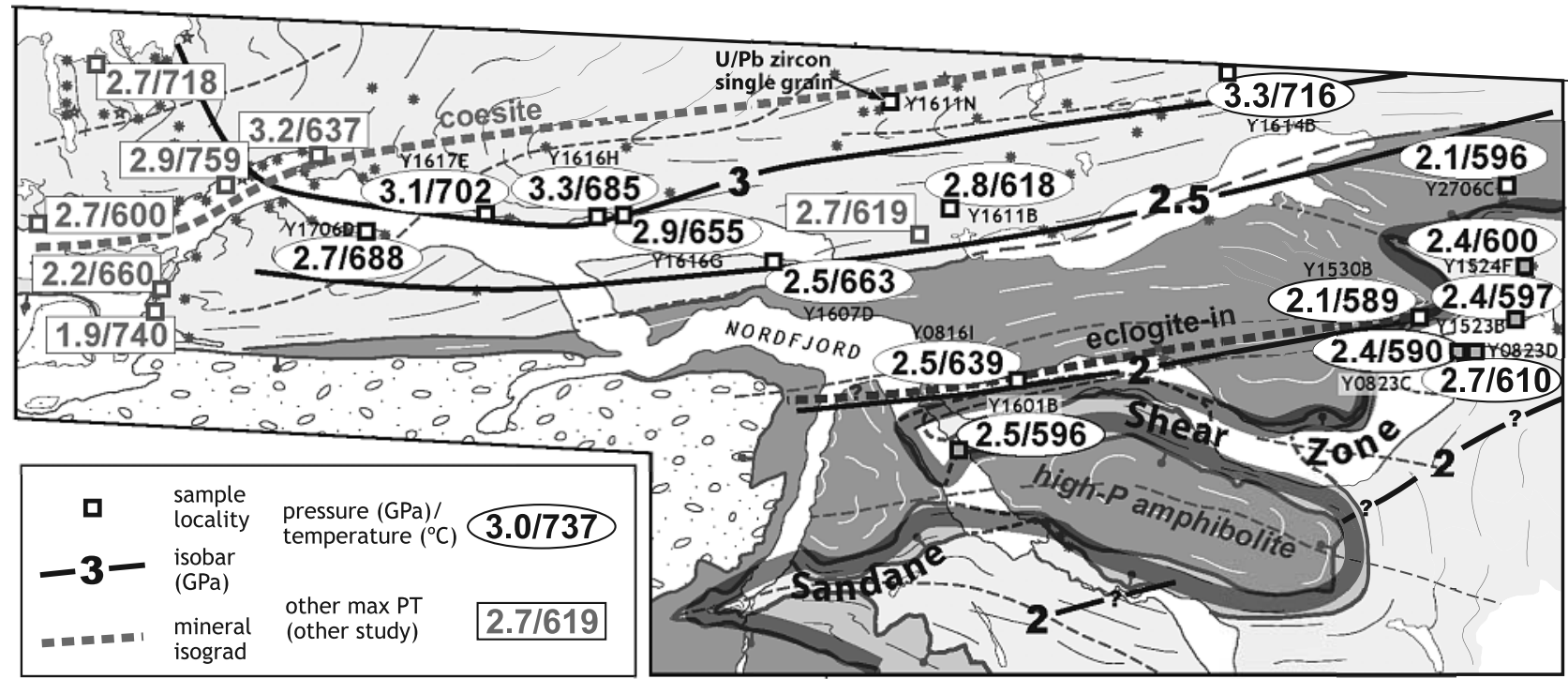

Figure 7. Inferred isograds and isobars across the Nordfjord region (derived from PT data of Cuthbert et al. [2000], Labrousse et al. [2004], Krogh Ravna and Terry [2004], and this study). A continuous increase from amphibolite-facies in the south-southeast to coesite-eclogite facies in the north-northwest is shown. The eclogite-in isograd north of Nordfjord refers to the appearance of eclogite in the Middle Allochthon; the same isograd has not been located at lower structural levels in the WGC but may broadly coincide with the $2 \mathrm{GPa}$ isobar in the southeast corner of the map. Y1611N single grain zircon sample is shown at top of map.

in the mantles of larger garnets is mirrored by increasing Mg \# (Figure 5b); Ca may increase or decrease rimward, but generally decreases in outermost rims. Hornblende inclusions in garnet are low-Al pargasite, whereas matrix hornblende has edenitic cores and higher $\mathrm{Ca} / \mathrm{Na}$ rims. Some omphacite grains have rimward decreasing jadeite ( 52-49 mol \%) with increasing $\mathrm{Mg} \#$, and a few phengite grains have cores with higher Si (3.36 pfu). These "cold", quartz-stable eclogites yield maximum pressures and temperatures around 1.9-2.2 GPa and $594-624^{\circ} \mathrm{C}$ (Figure 6 and Table 2).

\section{Single-Grain Zircon Geochronology}

[32] A considerable effort was directed toward establishing the age of the (U)HP metamorphic event, by spot analysis of zircons via secondary ion mass spectrometry (SIMS) and laser ablation multicollector inductively cou-
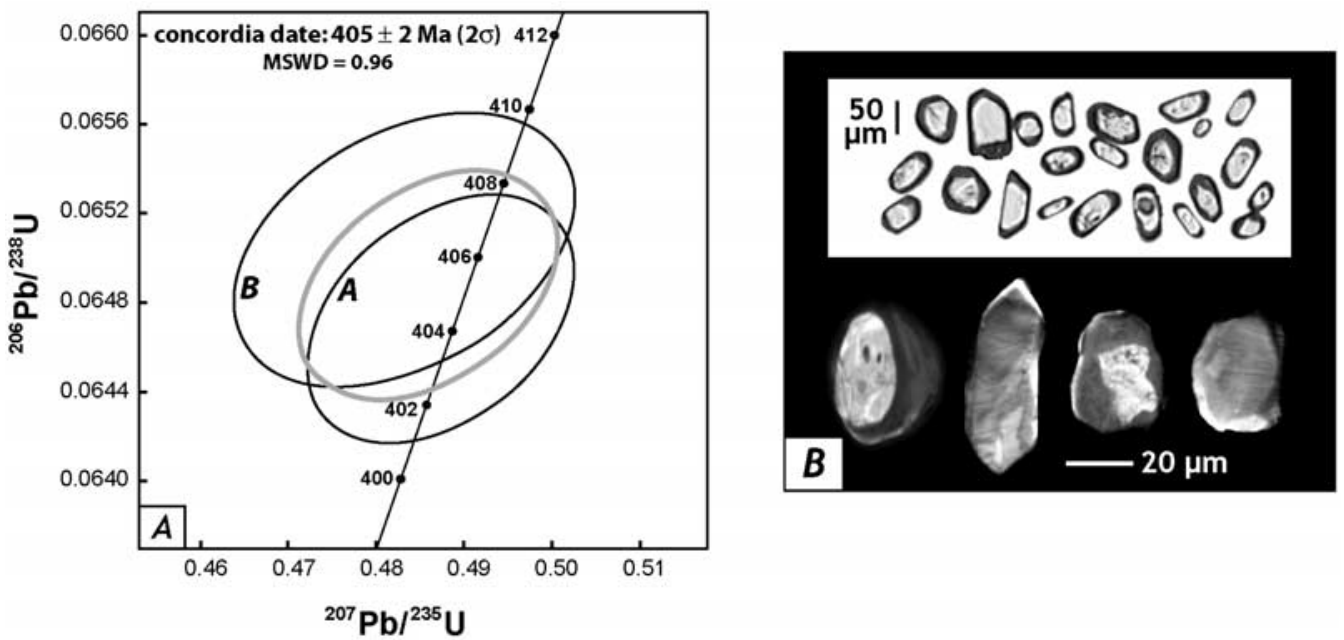

Figure 8. (a) Two single zircon grains from eclogite $\mathrm{Y} 1611 \mathrm{~N}$ give a weighted mean date (gray ellipse) of $405 \pm 2 \mathrm{Ma}$. (b) Y1611N zircons are subhedral prisms (plane light, top) with mottled cathodoluminescence (bottom). 
Table 3. U-Pb Data for Single-Grain ID-TIMS ${ }^{\mathrm{a}}$

\begin{tabular}{|c|c|c|c|c|c|c|c|c|c|c|}
\hline Grain & $\mathrm{U}, \mathrm{ppm}$ & Weight $\mathrm{Pb}, \mathrm{pg}$ & $\mathrm{Pbc}^{\mathrm{b}}, \mathrm{pg}$ & ${ }^{206} \mathrm{~Pb} /{ }^{204} \mathrm{~Pb}^{\mathrm{c}}$ & ${ }^{207} \mathrm{~Pb} /{ }^{235} \mathrm{U}_{\text {Ratio }}{ }^{\mathrm{d}}$ & ${ }^{206} \mathrm{~Pb} /{ }^{238} \mathrm{U}_{\text {Ratio }}{ }^{\mathrm{d}}$ & $\rho$ & ${ }^{207} \mathrm{~Pb} /{ }^{206} \mathrm{~Pb}$ Ratio $^{\mathrm{d}}$ & ${ }^{206} \mathrm{~Pb} /{ }^{238} \mathrm{U}$ Date ${ }^{\mathrm{d}}$ & ${ }^{207} \mathrm{~Pb} /{ }^{235} U$ Date ${ }^{\mathrm{d}}$ \\
\hline A & $>38$ & 2.74 & 0.5 & 309.7 & $0.4873(2.5)$ & $0.06473(0.70)$ & 0.38 & $0.0546(2.3)$ & $404.3[2.8]$ & $403[9.0]$ \\
\hline $\mathrm{B}$ & $>31$ & 2.38 & 0.6 & 245.7 & $0.4831(3.2)$ & $0.06504(0.76)$ & 0.38 & $0.0539(3.0)$ & $406.2[3.0]$ & $400[11.0]$ \\
\hline
\end{tabular}

${ }^{\mathrm{a}}$ Values in parentheses indicate $\pm 2 \sigma$ absolute error; $\rho$ is correlation coefficient

${ }^{\mathrm{b}} \mathrm{Pbc}$, total common $\mathrm{Pb}$ in sample (initial +blank).

${ }^{\mathrm{c}}$ Raw data corrected for fractionation and blank.

${ }^{\mathrm{d}}$ Corrected for fractionation, spike, blank and initial common $\mathrm{Pb}$; error calculated by propagating the main sources of uncertainty.

pled plasma mass spectrometry (LA-MC-ICPMS). Six eclogites were sampled: five from the WGC in eastern and northern Nordfjord (Y0823C, Y1523D, Y1611B, Y1611L6, and Y1611N), and a single sample from the Lower Allochthon (Y1601B). Unfortunately, significant inheritance of Precambrian cores and relatively minor recrystallization or new zircon growth during the eclogitefacies event precluded an accurate determination of the age of Scandian high-P metamorphism from these methods. However, two eclogites (Y1611N and Y1601B) contained a subpopulation of small $(<80 \mu \mathrm{m})$, subhedral or euhedral zircons (Figure 8) with $\mathrm{Th} / \mathrm{U}$ ratios and patchy-mottled cathodoluminescence (CL) response typical of metamorphic zircon, and spot ages of $\sim 400 \mathrm{Ma}$, suggesting limited inheritance.

[33] Five subhedral zircons of this type from eclogite Y1611N were sent to the University of Oslo; two were analyzed individually by ID-TIMS (Table 3 and Figure 8), using analytical protocols described by Corfu [2004]. $\mathrm{Y} 1611 \mathrm{~N}$ is a large float sample of medium- to coarsegrained, well-recrystallized eclogite with homogeneous garnet; it lacks quartz and phengite but contains zoisite. Although not in situ, this sample is compositionally and texturally similar to nearby eclogite, from which we could not easily collect fresh samples. A pressure above $2.5 \mathrm{GPa}$ is inferred from the well-recrystallized, granoblastic texture (Figure 4b), lack of garnet zoning, and proximity to UHP eclogite [cf. Cuthbert et al., 2000]. Petrography and backscattered-electron imaging reveal that zircons of this size $(20-80 \mu \mathrm{m})$ and morphology are abundant and occur in all high-P phases. Small zircons included in garnets are more numerous in the garnet rims, and are locally associated with rutile. In $\mathrm{CL}$ these grains have patchy, mottled sector zoning, occasionally with bright cores (Figure 8b). Whether such zircons grew at HP is difficult to assess, but they certainly did not grow during the amphibolite-facies overprint.

[34] The TIMS analyses show that both grains are low in $\mathrm{U}(>38 \mathrm{ppm})$, typical for metamorphic zircon. Grain A returned concordant ${ }^{206} \mathrm{~Pb} /{ }^{238} \mathrm{U}$ and ${ }^{207} \mathrm{~Pb} /{ }^{235} \mathrm{U}$ dates of $404 \pm 2 \mathrm{Ma}$ and $403 \pm 9 \mathrm{Ma}$ respectively, whereas grain $\mathrm{B}$ gave ${ }^{206} \mathrm{~Pb} /{ }^{238} \mathrm{U}$ and ${ }^{207} \mathrm{~Pb} /{ }^{235} \mathrm{U}$ dates of $406 \pm 3 \mathrm{Ma}$ and $400 \pm 11 \mathrm{Ma}$ (Table 3). A weighted mean of these analyses gives a concordia date of $405 \pm 2 \mathrm{Ma}$ with an MSWD of 0.96. No inheritance is resolvable in these zircons; they represent new growth during Scandian metamorphism.
Because of the textures described above, we consider $405 \pm 2 \mathrm{Ma}$ to approximate the age of the UHP metamorphism in northern Nordfjord; this estimate is consistent with eclogite geochronology elsewhere in western Norway [Carswell et al., 2003; Krogh et al., 2003; Root et al., 2004].

\section{Discussion}

\subsection{Regional Metamorphic Gradients and the Shape of the (U)HP Domains}

[35] Wain et al. [2000] and Cuthbert et al. [2000] recognized that many Nordfjord-Stadlandet UHP eclogites formed by overprinting of lower pressure assemblages and identified a transition zone between HP and UHP eclogites in outer Nordfjord-Stadlandet. These authors concluded that the boundary between the two metamorphic domains might be a structural discontinuity, or result from kinetic factors.

[36] Textural evidence, mineral zoning and garnetomphacite-phengite \pm kyanite thermobarometry from the current study demonstrate that the regional transition from amphibolite facies $(<1.8 \mathrm{GPa})$ to coesite-eclogite facies $(>3 \mathrm{GPa})$ is a continuous, relatively smooth $\mathrm{P}-\mathrm{T}$ gradient developed over a lateral distance of $\sim 20 \mathrm{~km}$ and a strike length of $\geq 80 \mathrm{~km}$ (Figure 7). Given these data, one can draw relatively evenly spaced pressure contours that are uninterrupted by major discontinuities or structural breaks. Aside from minor displacement of the eclogite-in isograd caused by the SSZ and the Bortnen Fault, we find no compelling evidence in the thermobarometry of any structural feature defining or disrupting this transition.

[37] Eclogite P-T estimates from the southeastern WGC in the study area overlap those reported from the WGC farther south: $\sim 2.1-2.3 \mathrm{GPa}$ at $550-615^{\circ} \mathrm{C}$ around Sunnfjord [Cuthbert et al., 2000; Labrousse et al., 2004; Foreman et al., 2005], and $\sim 2.3 \mathrm{GPa} / 700^{\circ} \mathrm{C}$ at western Sognefjord [Hacker et al., 2003]. The age of the eclogite-facies metamorphism in the Sunnfjord-Sognefjord area has not been determined, but the similarity in metamorphic pressures and temperatures, as well as prograde eclogite textures, to the inner Nordfjord area implies that all may have formed during a single Scandian HP event. Consequently, a large area from Sognefjord north to inner Nordfjord $(170 \mathrm{~km} \times$ $40 \mathrm{~km}$ ) may have been buried to and exhumed from a rather uniform depth of $\sim 70-80 \mathrm{~km}$. 


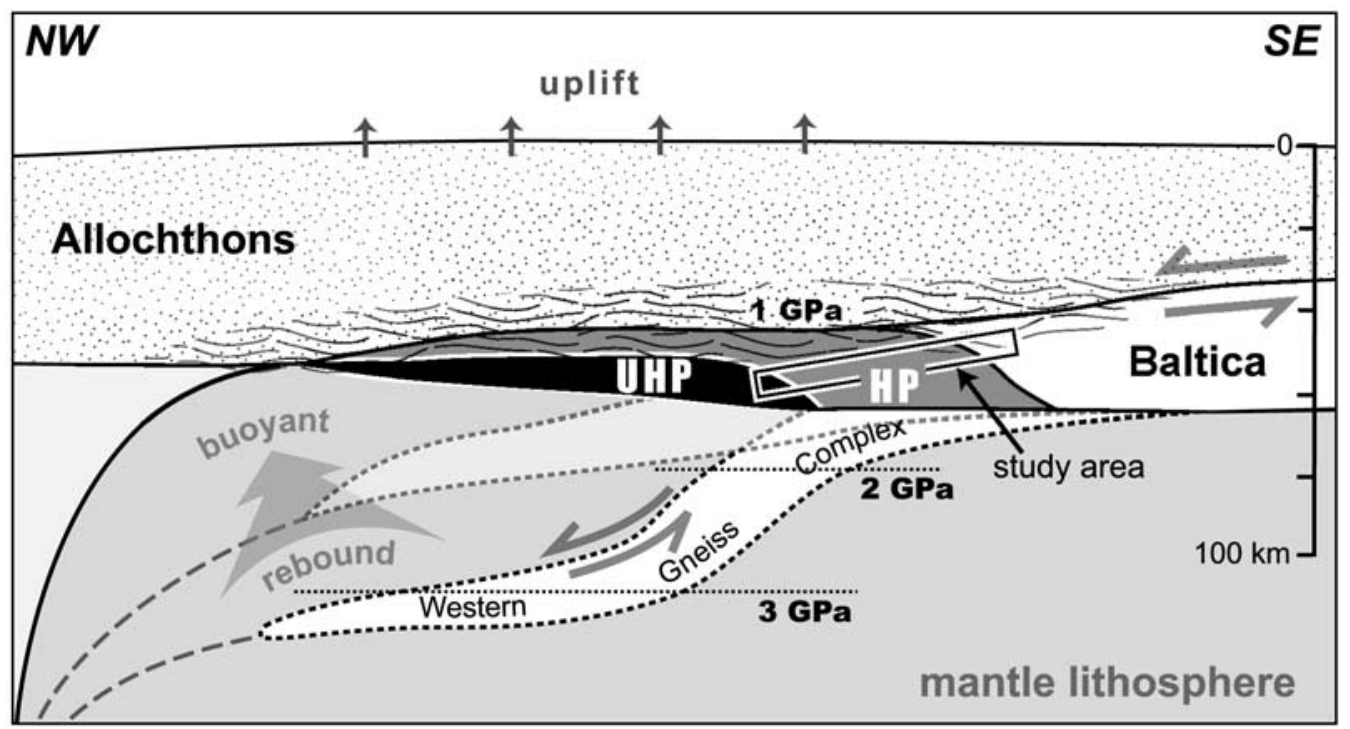

Figure 9. Buoyant rebound of detached continental lithosphere, coupled with back slip along the subduction horizon, exhumes the Nordfjord HP/UHP terrane from peak pressures $>3 \mathrm{GPa}$ to continental Moho depths. Approximate level of study area is marked by box. $\mathrm{V}: \mathrm{H}$ scale $=1: 1$. Depth/isobar conversion is approximate $(\mathrm{P}=\rho \mathrm{gh})$.

[38] By contrast, north of Nordfjord, maximum eclogite pressures reach 3.0-3.9 GPa, implying more profound burial and exhumation from depths greater than $100 \mathrm{~km}$. Significantly, Nordfjord also marks the southern limit of mantle peridotite bodies in the WGC (Figure 2) [cf. Brueckner, 1998]. These features suggest that the WGC to the north lay beneath a mantle wedge, which must have been excised or bypassed during the exhumation of the HP-UHP rocks.

\subsection{Boundaries of the (U)HP Rocks}

[39] The presence of eclogites with similar pressures and temperatures above and below the SSZ indicates that the SSZ was not responsible for major exhumation of the UHP rocks. The first-order extensional shear zone that must have overlain the (U)HP crust and accommodated movement with respect to overlying mantle is not exposed in the study area, and must be located at higher structural levels.

[40] Recognition of a continuous gradient from amphibolite facies to UHP eclogite places important limits on the exhumation geometry of the WGC in this region, indicating that the U(HP) rocks remained attached to lower pressure rocks to the south and east, i.e., updip in the same slab, during their return through the mantle.

[41] If no structure separates the HP/UHP domains from parautochthonous Baltica in the Nordfjord area, could one exist elsewhere, or is there a continuous, unbroken section all the way from the UHP domains to the low-grade rocks in the foreland? If a structure exists it must necessarily underlie all late Scandian eclogites, which are exposed across the WGC almost to the Trondheim nappes (Figure 2) [Walsh and Hacker, 2004]. In addition, a smooth gradient in $\mathrm{U} / \mathrm{Pb}$ sphene ages [Tucker et al., 2004] implies that a large swath of the northeastern WGC remained coherent after $395 \pm 2 \mathrm{Ma}$. The northeastern boundary of the Trondheim nappes cannot be the structure in question because it is an east dipping extensional feature that overlies the WGC [Hacker and Gans, 2005]; therefore any subeclogite décollement must extend farther east. In the Sunnfjord and Sognefjord areas, eclogites do not extend far across the WGC, raising the possibility that a subeclogite décollement may surface in the WGC in this area. However, detailed mapping and geochronology along Sognefjord has not revealed any such feature, but rather an eastward decrease in Caledonian deformation giving way to undisturbed Proterozoic basement [Dietler et al., 1985; Milnes et al., 1997; Skår, 2000]. These constraints leave three possibilities: (1) the UHP-HP rocks were thrust onto lower pressure rocks of Baltica along a décollement that passes beneath the WGC and the entire Trondheim/Jotun nappe stack and surfaces in the foreland [Tucker et al., 2004]; (2) the $\mathrm{UHP}-\mathrm{HP}$ rocks were thrust onto lower pressure rocks of Baltica along a fault now covered by the Trondheim/Jotun nappe stack; or (3) no such fault ever existed and the transition from UHP-HP rocks to the Baltica craton is gradational.

[42] These possibilities might be testable through seismic profiling and study of the depositional and deformational history of the foreland. However, reflection and refraction seismic studies [Iwasaki et al., 1994; Hurich, 1996] have not resolved whether a floor thrust lies beneath the WGC. An imaged décollement 9-15 km beneath the Scandian nappe pile projects to the surface in the foreland [Hurich, 1996], but the magnitude of exhumation along this structure is unknown. If a floor thrust surfaced in or near the foreland, one might expect large-scale subsidence and sedimentation produced by the eastward thrusting of a rock mass as large 
as $200 \mathrm{~km} \times 400 \mathrm{~km} \times 5-10 \mathrm{~km}$ (the present size of the WGC). The foreland basin of the Scandes was relatively thin [Middleton et al., 1996], suggesting that flexural loading of the craton did not increase late in the collision, although Plink-Bjørklund and Bjørklund [1999] have proposed that the basin might later have been partially eroded. The time that convergence ceased in the foreland is also unclear because of the difficulties in dating continental sedimentary rocks. Fossen and Dunlap [1998] used muscovite ${ }^{40} \mathrm{Ar} /{ }^{39} \mathrm{Ar}$ ages to argue that extension and exhumation were underway in the foreland and southern WGC by $\sim 402 \mathrm{Ma}$, but this does not preclude continued shortening at deeper levels.

[43] In summary, while it is possible that a décollement underlies the entire WGC and surfaces in the foreland, work directed toward solving this important question has failed to recognize the postulated structure. In contrast, studies of the Nordøyane area have documented contractional eclogitefacies shear zones, and juxtaposition of UHP units over lower pressure crust [Terry and Robinson, 2004]. These relationships are interpreted as thrust imbrication of the outer Baltica margin during maximum burial with transferral of slices to the hanging wall of the subduction interface; similar structural relationships were not observed in the Nordfjord area.

[44] Because the Scandian tectonostratigraphy and thermobaric gradient in the Nordfjord area remained coherent, we conclude that at least the Nordfjord region remained attached to crust updip (south and eastward) in the slab during eclogite metamorphism and exhumation. Such geometries are inconsistent with exhumation mechanisms that require significant circulation and mixing in the subduction channel [e.g., Burov et al., 2001; Gerya et al., 2002]. Bulk extrusion (Figure 1b) cannot be discounted given our current understanding of the crustal structure beneath the WGC; however, evidence for such a structure is weak. Lithosphere-scale normal faulting (Figure 1a), and/or slab failure with flexural rebound (Figures 1d and 9) are also permissible mechanisms by which a coherent crustal section could have been exhumed through the mantle.

\section{Conclusions}

[45] Peak metamorphic grade in the Nordfjord area of western Norway increases steadily north-northwestward from high-pressure amphibolite facies to coesite-eclogite facies. This gradient is reflected in a continuous textural evolution in mafic rocks, from hornblende and epidotebearing, prograde-zoned, incompletely recrystallized eclogite, to coarse, high-variance, unzoned UHP assemblages. Thermobarometric calculations indicate $\mathrm{P}-\mathrm{T}$ conditions increase from $\sim 1.5 \mathrm{GPa} / 600-700^{\circ} \mathrm{C}$ in the south to $>2.7 \mathrm{GPa} / 700^{\circ} \mathrm{C}$ in the north. The absence of any significant metamorphic and structural breaks within this transition implies that the UHP rocks remained attached to lower pressure crust updip during exhumation, and that the Nordfjord area is part of a crustal section that was exhumed relatively intact. These findings favor models that allow significant areas of crust to remain coherent during metamorphism and exhumation.

[46] Acknowledgments. Thanks to Julia Baldwin, Simon Cuthbert, Michael Terry, and an anonymous reviewer for improvements to the manuscript; David Pierce at University of California, Santa Barbara, for assistance with the electron microprobe; and Roger Powell for his garnetclinopyroxene thermometry code. This research was funded by National Science Foundation grant EAR-9814889, the Sigma Xi Society, the Geological Society of America and the University of California.

\section{References}

Andersen, T. B. (1998), Extensional tectonics in the Caledonides of southern Norway, an overview, Tectonophysics, 285, 333-351.

Andersen, T. B., B. Jamtveit, J. F. Dewey, and E. Swensson (1991), Subduction and eduction of continental crust: Major mechanism during continent-continent collision and orogenic extensional collapse, a model based on the south Caledonides, Terra Nova, 3, 303-310.

Andersen, T. B., P. T. Osmundsen, and L. Jolivet (1994), Deep crustal fabrics and a model for the extensional collapse of the southwest Norwegian Caledonides, J. Struct. Geol., 16(9), 1191-1203.

Brueckner, H. K. (1998), Sinking intrusion model for the emplacement of garnet-bearing peridotites into continent collision orogens, Geology, 26, 631634.

Bryhni, I. (2000a), Bedrock map HORNINDAL 1318IV, Norw. Geol. Surv., Oslo.

Bryhni, I. (2000b), Bedrock map NORDFJORDEID 1218 I, Norw. Geol. Surv., Oslo.

Bryhni, I., and O. Lutro (2000), Bedrock map FIMLANDSGREND 1218 II, Norw. Geol. Surv., Oslo.

Bucher, K., and M. Frey (2002), Petrogenesis of Metamorphic Rocks, Springer, New York.

Burov, E., L. Jolivet, L. Le Pourhiet, and A. Poliakov (2001), A thermomechanical model of exhumation of high pressure (HP) and ultra-high pressure (UHP) metamorphic rocks in Alpine-type collision belts, Tectonophysics, 342, 113-136.
Carswell, D. A., P. J. O'Brien, R. N. Wilson, and M. Zhai (1997), Thermobarometry of phengitebearing eclogites in the Dabie Mountains of centra China, J. Metamorph. Geol., 15, 239-252.

Carswell, D. A., H. K. Brueckner, S. J. Cuthbert, K. Mehta, and P. J. O'Brien (2003), The timing of stabilisation and the exhumation rate for ultra-high pressure rocks in the Western Gneiss Region of Norway, J. Metamorph. Geol., 21, 601-612.

Chemenda, A. I., M. Mattauer, J. Malavieille, and A. N Bokun (1995), A mechanism for syn-collisiona rock exhumation and associated normal faulting: Results from physical modelling, Earth Planet Sci. Lett., 132, 225-232.

Chopin, C., C. Henry, and A. Michard (1991), Geology and petrology of the coesite-bearing terrain, Dora Maira massif, western Alps, Eur. J. Mineral., 3, $263-291$.

Corfu, F. (2004), U-Pb age, setting, and tectonic significance of the anorthosite-mangerite-charnockitegranite-suite, Lofoten-Vesterålen, Norway, J. Petrol., 45, 1799-1819.

Cuthbert, S. J., D. A. Carswell, E. J. Krogh Ravna, and A. Wain (2000), Eclogites and eclogites in the Western Gneiss Region, Norwegian Caledonides, Lithos, 52, 165-195

Dietler, T. N., A. G. Koestler, and A. G. Milnes (1985), A preliminary structural profile through the Western Gneiss Complex, Sognefjord, southwestern Norway, Nor. Geol. Tidsskr., 65, 233-235.
Foreman, R., T. B. Andersen, and J. Wheeler (2005), Eclogite facies polyphase deformation of the Drøsdal eclogite, Western Gneiss Complex, Norway, and implications for exhumation, Tectonophysics, 398 , $1-32$.

Fossen, H. (2000), Extensional tectonics in the Caledonides: Synorogenic or postorogenic?, Tectonics, 19(2), 213-224.

Fossen, H., and W. J. Dunlap (1998), Timing and kinematics of Caledonian thrusting and extensional collapse, southern Norway; evidence from ${ }^{40} \mathrm{Ar} /{ }^{39} \mathrm{Ar}$ thermochronology, J. Struct. Geol., 20, 765-781.

Fossen, H., and E. Rykkelid (1992), Postcollisional extension of the Caledonide orogen in Scandinavia: Structural expressions and tectonic significance, Geology, 20, 737-740.

Ganguly, J., W. Cheng, and M. Tirone (1996), Thermodynamics of aluminosilicate garnet solid solution: New experimental data, an optimized model, and thermometric applications, Contrib. Mineral. Petrol., 126, 137-151.

Gerya, T. V., B. Stöckhert, and A. L. Perchuk (2002), Exhumation of high-pressure metamorphic rocks in a subduction channel: A numerical simulation, $T e c-$ tonics, 21(6), 1056, doi:10.1029/2002TC001406.

Grasemann, B., L. Ratschbacher, and B. R. Hacker (1998), Exhumation of ultrahigh-pressure rocks: Thermal boundary conditions and cooling history, in When Continents Collide: Geodynamics and Geochemistry of Ultrahigh-Pressure Rocks, edited 
by B. R. Hacker and J. G. Liou, pp. 117-139, Springer, New York.

Hacker, B. R. (2006), Pressures and temperatures of ultrahigh-pressure metamorphism: Implications for UHP tectonics and $\mathrm{H}_{2} \mathrm{O}$ in subducting slabs, Int. Geol. Rev., in press.

Hacker, B. R., and P. B. Gans (2005), Creation of ultrahigh-pressure terranes: The Trondelag - Jämtland region of the Scandinavian Caledonides, Geol. Soc. Am. Bull., 117, 117-134

Hacker, B. R., and S. M. Peacock (1995), Creation, preservation, and exhumation of coesite-bearing, ultrahigh-pressure metamorphic rocks, in Ultrahigh Pressure Metamorphism, edited by R. G. Coleman and X. Wang, pp. 159-181, Cambridge Univ. Press, New York.

Hacker, B. R., L. Ratschbacher, L. E. Webb, T. R. Ireland, A. Calvert, S. Dong, H.-R. Wenk, and D. Chateigner (2000), Exhumation of ultrahigh-pressure continental crust in east-central China: Late Triassic-Early Jurassic tectonic unroofing, J. Geophys. Res, 105, 13,339-13,364.

Hacker, B. R., T. B. Andersen, D. B. Root, L. Mehl, J. M. Mattinson, and J. L. Wooden (2003), Exhumation of high-pressure rocks beneath the Solund Basin, Western Gneiss Region of Norway, J. Metamorph. Geol., 21, 612-629.

Holland, T. J. B., and R. Powell (1998), An internally consistent thermodynamic data set for phases of petrological interest, J. Metamorph Geol, 16, 309-343.

Hossack, J. R., and M. A. Cooper (1986), Collision tectonics in the Scandinavian Caledonides, in Collision Tectonics, edited by M. P. Coward and A. C. Ries, Geol. Soc. Spec. Pap., 19, 287-304.

Hurich, C. A. (1996), Kinematic evolution of the lower plate during intracontinental subduction: An example from the Scandinavian Caledonides, Tectonics, $15,1248-1263$.

Iwasaki, T., M. A. Sellevoll, T. Kanazawa, T. Veggeland, and H. Shimamura (1994), Seismic crustal refraction study along the Sognefjord, southwest Norway, employing ocean-bottom seismometers, Geophys. J. Int., 119, 791-808.

Krabbendam, M., and J. F. Dewey (1998), Exhumation of UHP rocks by transtension in the Western Gneis Region, Scandinavian Caledonides, in Continental Transpressional and Transtensional Tectonics, edited by R. E. S. Holdsworth, R. A. Strachan, and J. F. Dewey, Geol. Soc. Spec. Publ., 135, 159-181.

Krabbendam, M., and A. Wain (1997), Late-Caledonian structures, differential retrogression and structural position of (ultra) high pressure rocks in the Nordfjord-Stadlandet area, Western Gneiss Region, Norges Geol. Under. Bull., 432, 127-139.

Krogh, T., P. Robinson, and M. P. Terry (2003), Precise $\mathrm{U}-\mathrm{Pb}$ zircon ages define 18 and 19 m.y. subduction to uplift intervals in the Averøya-Nordøyane area, Western Gneiss Region, International Eclogite Conference, Selje, Norway, $21-28$ June.

Krogh Ravna, E. (2000), The garnet-clinopyroxene $\mathrm{Fe}^{2+}-\mathrm{Mg}$ geothermometer: An updated calibration, J. Metamorph. Geol., 18, 211-219.

Krogh Ravna, E., and M. P. Terry (2004), Geothermobarometry of UHP and HP eclogites and schists-An evaluation of equilibria among garnetclinopyroxene-kyanite-phengite-coesite/quartz, J. Metamorph. Geol., 22, 579-592.

Labrousse, L., L. Jolivet, T. B. Andersen, P. Agard, H. Maluski, and U. Schärer (2004), Pressure- temperature-time-deformation history of the exhumation of ultra-high pressure rocks in the Western Gneiss Region, Norway, Spec. Pap. Geol. Soc. Am., 380, 155-185.

Middleton, M. F., E.-L. Tullborg, S. A. Larson, and L. Bjørklund (1996), Modelling of a Caledonian foreland basin in Sweden: Petrophysical constraints, Mar. Pet. Geol., 13, 407-415.

Milnes, A. G., O. P. Wennberg, Ø. Skår, and A. G. Koestler (1997), Contraction, extension, and timing in the South Norwegian Caledonides: The Sognefjord transect, in Orogeny Through Time, edited by J.-P. Burg and M. Ford, Geol. Soc. Spec. Publ., 121, $123-148$.

Newton, R. C., and H. T. Haselton (1981), Thermodynamics of the garnet-plagioclase- $\mathrm{Al}_{2} \mathrm{SiO}_{5}$-quartz geobarometer, in Thermodynamics of Minerals and Melts, edited by R. C. Newton, A. Navrotsky, and B. J. Wood, pp. $131-147$, Springer, New York.

Nowlan, E. U., H.-P. Schertl, and W. Schreyer (2000), Garnet-omphacite-phengite thermobarometry of eclogites from the coesite-bearing unit of the southern Dora-Maira Massif, western Alps, Lithos, 52, 197-214.

Plink-Bjørklund, P., and L. Bjørklund (1999), Sedimentary response in the Baltic Devonian Basin to postcollisional events in the Scandinavian Caledonides, Geol. Foeren. Stockholm Foerh., 121, 79-80.

Poli, S. (1993), The amphibolite-eclogite transformation; an experimental study on basalt, Am. J. Sci., 293, 1061-1107.

Roberts, D., and D. G. Gee (1985), An introduction to the structure of the Scandinavian Caledonides, in The Caledonide Orogen-Scandinavia and Related Areas, edited by D. G. Gee and B. A. Sturt, pp. $55-$ 68, John Wiley, Hoboken, N. J.

Roberts, D., and M. B. Stephens (2000), Caledonian Orogenic Belt, in Description to the Bedrock Map of Fennoscandia (Mid-Norden), Geol. Surv. Fin land Spec. Pap. 28, edited by T. Lundqvist and S. Autio, pp. 79-104, Geol. Surv. of Finland, Helsinki.

Root, D. B., B. R. Hacker, J. M. Mattinson, and J. L. Wooden (2004), Young age and rapid exhumation of Norwegian ultrahigh-pressure rocks: An ion microprobe and chemical abrasion study, Earth Planet. Sci. Lett., 228, 325-341.

Root, D. B., B. R. Hacker, P. Gans, E. Eide, M. Ducea, and J. Mosenfelder (2005), Highpressure allochthons overlie the ultrahigh-pressure Western Gneiss Region, Norway, J. Metamorph. Geol., 23, 45-61.

Schmid, J. C., L. Ratschbacher, I. Gaitzsch, B. R. Hacker, and S. Dong (1999), How did the foreland react? Yangtze foreland fold-and-thrus belt deformation related to exhumation of the Dabie Shan ultrahigh-pressure continental crust (eastern China), Terra Nova, 11, 266-272.

Skår, Ø. (2000), Field relations and geochemical evolution of the Gothian rocks in the Kvamsøy area southern Western Gneiss Region, Norway, Norges Geol. Under. Bull., 437, 5-23.

Smith, D. C. (1984), Coesite in clinopyroxene in the Caledonides and its implication for geodynamics, Nature, 310, 641-644.

Smith, D. C. (1988), A review of the peculiar mineralogy of the "Norwegian eclogite province", with crystal chemical, petrological, geochemical an geodynamical notes and an extensive bibliography, in Eclogites and Eclogite-Facies Rocks, edited by D. C. Smith, pp. 1-206, Elsevier, New York

Stipska, P., and R. Powell (2005), Constraining the P-T path of a MORB-type eclogite using pseudosections, garnet zoning and garnet-clinopyroxene thermometry: An example from the Bohemian Massif, J. Metamorph. Geol., 23, 725-743.

Terry, M. P., and P. Robinson (2004), Geometry of eclogite-facies structural features: Implications for production and exhumation of ultrahigh-pressure and high-pressure rocks, Western Gneiss Region, Norway, Tectonics, 23, TC2001, doi:10.1029/ 2002TC001401

Terry, M. P., P. Robinson, M. A. Hamilton, and M. J. Jercinovic (2000a), Monazite geochronology of UHP and HP metamorphism, deformation, and exhumation, Nordøyane, Western Gneiss Region, Norway, Am. Mineral., 85, 1651-1664.

Terry, M. P. P. Robinson, and E. J. K. Ravna (2000b), Kyanite eclogite thermobarometry and evidence for thrusting of UHP over HP metamorphic rocks, Nordøyane, Western Gneiss Region, Norway, Am. Mineral., 85, 1637-1650.

Tucker, R. D., P. Robinson, A. Solli, D. G. Gee, T. Thorsnes, T. E. Krogh, Ø. Nordgulen, and M E. Bickford (2004), Thrusting and extension in the Scandian Hinterland, Norway: New U-Pb ages and tectonostratigraphic evidence, Am. J. Sci., 304 , $477-532$.

Wain, A. (1997), New evidence for coesite in eclogite and gneisses: Defining an ultrahigh-pressure province in the Western Gneiss Region of Norway, Geology, 25, 927-930.

Wain, A., D. Waters, A. Jephcoat, and H. Olijnyk (2000), The high-pressure to ultrahigh-pressure transition in the Western Gneiss Region, Norway, Eur. J. Mineral., 12, 667-687.

Walsh, E. O., and B. R. Hacker (2004), The fate of subducted continental margins: Two-stage exhumation of the high-pressure to ultrahigh-pressure Western Gneiss Complex, Norway, J. Metamorph. Geol., 22, 671-687.

Waters, D. J., and H. N. Martin (1993), Geobarometry of phengite-bearing eclogites, Terra Abstr., 5, 410411

Wilks, S. J., and S. J. Cuthbert (1994), The evolution of the Hornelen Basin detachment system, western Norway: Implications for the style of late orogenic extension in the southern Scandinavian Caledonides, Tectonophysics, 238, 1-30.

Yamamoto, H., M. Ishikawa, R. Anma, and Y. Kaneko (2000), Kinematic analysis of ultrahigh-pressureultrahigh-pressure metamorphic rocks in the Chaglinka-Kulet area of the Kokchetav Massif, Kazakhstan, Island Arc, 9, 304-316.

Yin, A., G. E. Gehrels, C. E. Manning, and C. Menold (2001), Tectonic erosion, diapiric flow, and emplacement of UHP rocks during oceanic subduction: Origin of the North Qaidam UHP gneisses, Geol. Soc. Am. Abstr. Programs, 33, 207.

T. B. Andersen and F. Corfu, Physics of Geological Processes and Department of Geosciences, University of Oslo, Blindern N-0316 Oslo, Norway.

B. R. Hacker and D. J. Young, Department of Geological Sciences, University of California, Santa Barbara, CA 93106, USA. (dyoung@csufresno.edu) 